\title{
Estimating Agricultural Malmquist Total Factor Productivity for Some Arab Countries' Employing Data Envelope Analysis A Non Parametric Approach
}

\author{
Ahmed El-Kholei \\ Department of Agricultural Economics, Faculty of Agriculture, Menofia University, Egypt
}

\begin{abstract}
The present paper aims is to provide up to date information on agricultural growth over the past three decades (1980-2012) for nine of the largest agricultural producers in the Arab world. Namely are Algeria, Egypt, Iraq, Jordan, Morocco, Sudan, Syria, Tunisia and Yemen. The analysis employs nonparametric, output-based Malmquist technique Data Envelopment Analysis (DEA) to estimate TFP index numbers. It uses data drawn from FAO. In general, results throughout the period 1980-2012 show that the average annual growth rate of agricultural productivity reached $1.2 \%$. Efficiency changes contributed by a mere $0.2 \%$ while the rest $1 \%$ was provided by technical change. The country with the highest TFP growth is Jordan, with an impressive 3.7\% average annual growth in TFP. However, for Yemen and Algeria it reached about $3 \%$ each, Egypt (2\%), Sudan (0.8\%), Tunisia and Iraq (0.4\%).
\end{abstract}

Keywords: Data Envelope Analysis (DEA), Total Factor Productivity (TFP) , Egypt

\section{INTRODUCTION}

Agriculture has been and will continue to play vital role for humanity, because human welfare depends on the amount and stability of agricultural production, as determined by crop yield and cultivated area (Garibaldi et al., 2011).

Onjala (2002) argued that, the economic growth could be viewed as a process involving the entire economy's output performance; it mainly depends on the productivity of the country. Productivity, on the other hand, is essentially a microeconomic matter, focusing on how production units hire and use capital, labor, and other resource inputs in their output of goods and services. The direct link between productivity and economic growth is apparent in many ways. The sources of productivity growth over time have nowadays emerged as a central of growth and development.

As an objective of development policy, productivity growth has been difficult to achieve in many countries. For this reason, studies on sources of growth are a field of great importance to policy makers. The issue of productivity growth has drawn considerable attention over the last few decades, as it is considered, the major source of development for the agricultural sector, at a rate able to meet the demands for food and raw materials arising out of steady population growth. A country that falls short of achieving agricultural productivity growth may suffer deterioration, either of the foreign exchange balance, or of the internal terms of trade against industry, thereby also hindering industrial production (Hayami and Ruttan, 1970; Coelli and Rao, 2003). In contrast, a country that best utilizes its given resources within its agricultural sector may enjoy a significant comparative advantage in exporting markets.

Several studies have focused on this matter, using either Partial Factor Productivity (PFP) measures, most commonly labour productivity (e.g. Gutierrez , 2000; McErlean and Wu, 2003) or Total Factor Productivity (TFP) measures. The 
latter are typically analysed using either i) a production function approach (e.g. Hayami and Ruttan, 1970; Wiebe et al. 2000), ii) an index number approach, usually Tornqvist index (e.g. Mukherjee and Kuroda 2003), or iii) a Data Envelopment Analysis (DEA) approach, the DEA- based Malmquist index (e.g. Coelli and Rao, 2003; Ludena et al., 2005).

Nin and Yu (2008) argued that the least-squares econometric production function models and total factor productivity indices are normally used with times series data and assume that all production units are technically efficient. Whereas, DEA approach can be applied to across-section of firms, farms, regions or countries to compare their relative productivity. If panel data are available, production functions, DEA and stochastic frontiers can be used to measure both technical change and efficiency improvement.

The Malmquist index, pioneered by Caves et al. (1982) used on distance functions, has become extensively used in the measure and analysis of productivity after Färe et al. (1994) showed that the index can be estimated using a non-parametric approach (Data Envelope Analysis). The nonparametric Malmquist index (discussed later in detail) has been especially popular since it does not entail assumptions about economic behavior (profit maximization or cost minimization) and therefore does not require prices for its estimation. Also important is its ability to decompose productivity growth into two mutually exclusive and exhaustive components: changes in technical efficiency over time (catching-up) and shifts in technology over time (technical change).

The study will examine changes in agricultural productivity in the Arab countries, in which their geographical locations are presented in Figure 1.

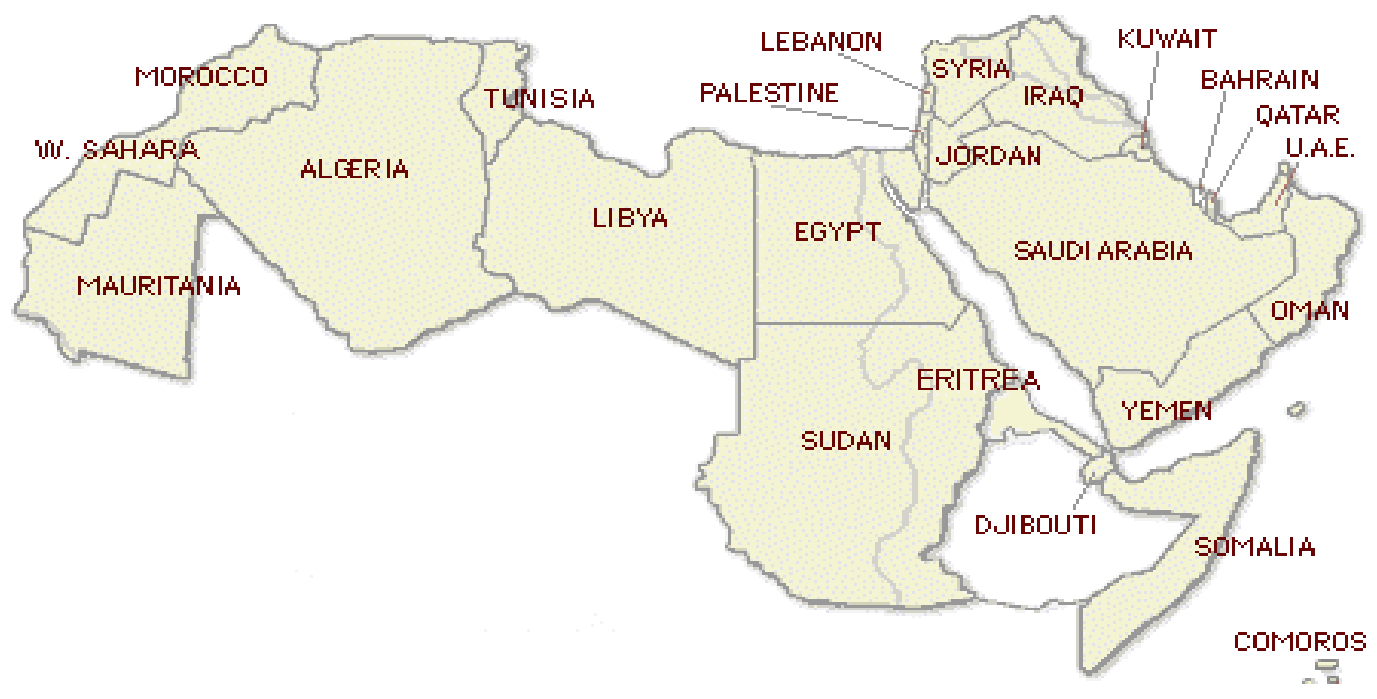

Figure (1): The Arab World Map

Source: Google maps 
Figure 2 shows the share of agricultural Gross Domestic Production (GDP) in Arab countries economies during the period 2008-2012 (on average). It depicts that the agricultural sector plays an important role in Sudan that contributes about $32 \%$ to its gross GDP, followed by Syria (21\%). Next come, Morocco, Egypt and Yemen (about $14 \%$ each on average). Whereas, Algeria and Tunisia accounted about $8 \%$ (each on average), Lebanon and Iraq nearly 5\% (each on average), Jordan, Libya and Saudi Arabia $2.5 \%$ on average. Finally, Emirates and Oman (0.9\% each), Bahrain and Kuwait ( $0.3 \%$ each) and Qatar ( $0.1 \%)$.

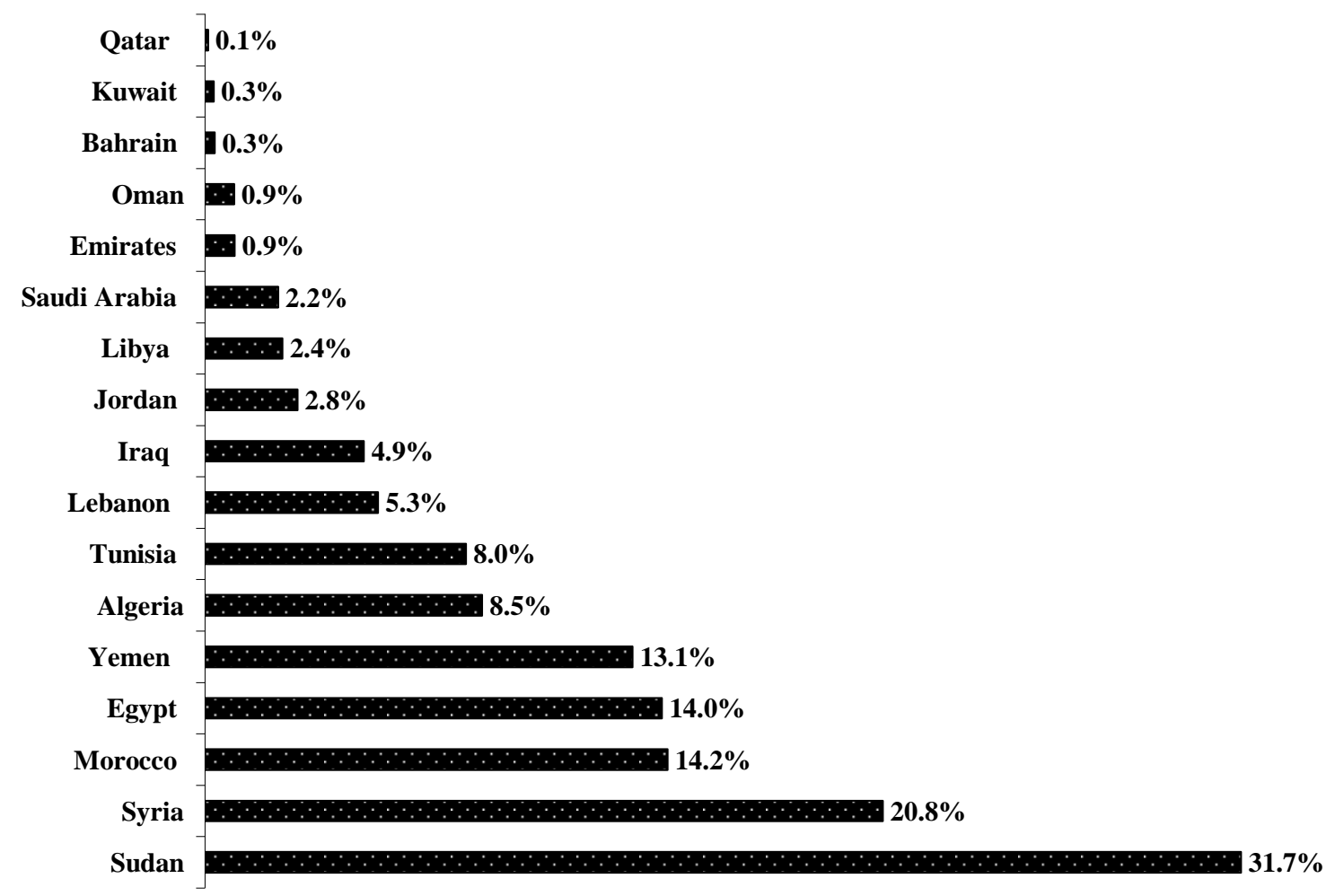

\section{Figure (2): The Share of Agricultural GDP in Country's GDP during the period 2008-2012 (on average)}

Source: Compiled and calculated from Arab Agricultural Statistics Yearbook (several issues)

The analysis dropped from the sample either the very small countries with negligible agriculture (such as Bahrain, Qatar, Kuwait, Oman and United Arab Emirates), or countries with missing data (such as Mauritania, Libya, Djibouti, Somalia, Comoros, Palestine, Lebanon and Saudi Arabia), in particular the study covers a relatively long period. Indeed almost the majority of sampled countries of this region continue to be extremely vulnerable to weather and commodity price shocks due to their limited economic resource base. They are prone to high volatility in economic activity, and therefore it is crucial to identify their sources of growth. (Belloumi and Matoussi, 2009). Thus, countries considered in this study are Algeria, Egypt, Iraq, Jordan, Morocco, Sudan, Syria, Tunisia and Yemen. The selected sample is considered the largest producers and importers of food and 
feed grains in the Arab world and a major global market for agricultural and food products, for example, Egypt is the largest wheat importer in the world.

The paper is structured as follows. The next section briefly discusses the aim of the paper. Data collection is the subject of part three. The forth section is devoted to give a background on DEA and Malmquist TFP index methodology. The paper's estimation process is the main topic for section five.The sixth section discusses the estimated results. The seventh and last section is devoted to conclusion.

\section{AIM OF THE PAPER}

The principle aim of this paper is to estimate and provide up to date information on agricultural total factor productivity (TFP) growth over the past three decades (1980-2012) for nine of the largest agricultural producers in the Arab world. Using the Malmquist index methods described in Fare et al. (1994) and Coelli et al. (1998, Ch. 10).

\section{DATA}

All data for the study period (2003-2012) are obtained from the World Bank, FAO Statistics Division and Arab Organization for Agricultural Development (AOAD)

\section{DEA MODEL AND MALMQUIST TFP METHODOLOGY}

In this section, the article provides a brief background and literature of DEA method, in addition to, Malmquist TFP before going on to describe the Malmquist TFP calculations.

\subsection{Background}

Technical efficiency (TE) is a component of economic efficiency (Farrell, 1957). It is defined as the ability of a firm to transform a given set of inputs into maximum achievable output given the available technology (Bravo-Ureta et al., 2007). When one considers productivity comparisons over time, an additional source of possible productivity improvements is technical change. It measures the extent to which the production frontier, representing the state of the technology in a particular time period, shifts upwards over time. Such shifts represent technological progress.

As cited from Rao et al. (2004), these two concepts are illustrated in Figure 3, where $F_{0}$ and $F_{1}$ represent the production frontiers for two periods 0 and 1 (in the case of a simple one-input, one-output technology). Focusing on $F_{0}$, for a given input level, the distance OB shows the level of output that could technically be produced under period 0 technology. If the actual production is below the technologically feasible level and it is given by level $O A$, then a measure of technical efficiency of the country (or farm) is given by the ratio OA/OB, which takes a value between zero and one, with one indicating technical efficiency. This is an output-orientated technical efficiency measure. 
An input-orientated technical efficiency measure is given by OC/OA showing the reduction input that is feasible, while maintaining the same output level. Technical change is measured by the shift in the frontiers represented by $\mathrm{F}_{0}$ and $F_{1}$. The measure of technical change varies according to the input (or output) level at which it measured. For example, in Figure 3 an output-orientated technical change measure is calculated as $0 \mathrm{~B}_{1} / \mathrm{OB}$, where a value greater than one indicates technical progress, Rao et al. (2004).

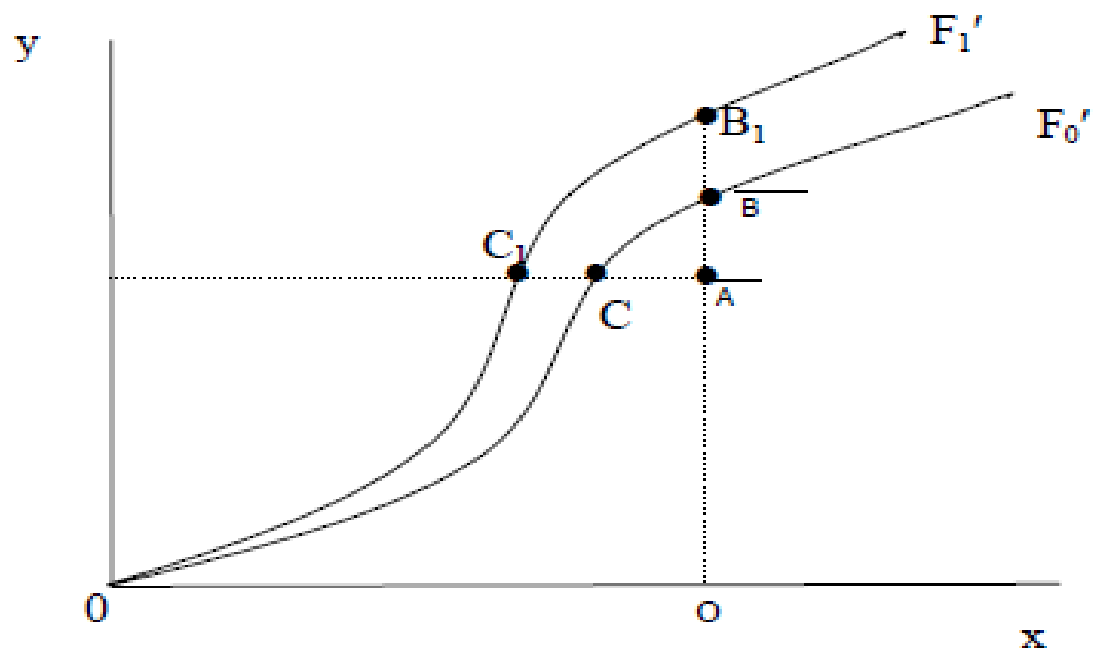

Figure (3): Technical change and technical efficiency change

Source: Rao et al. (2004)

Different types of frontier models based on the early work of Farrell (1957) have been developed for the measurement of technical efficiency. These models could be classified into parametric and non-parametric frontiers. Parametric frontier is further separated into two methods because they rely on a specific functional form (Aigner et al, 1977). These two groups are deterministic model which attributes any deviation to the inefficiency and the stochastic model which on the other hand tolerates statistical noise (Amara, et al., 1999). Non-parametric models are usually based on mathematical programming and also known as data envelopment analysis (DEA) (Banker et al, 1984), (Thiam et al, 2001). However, DEA only offers relative efficiencies relative to the data considered. It does not, and cannot, offer absolute efficiencies.

As cited by (Galanopoulos, 2006), the DEA models are linear programming (LP) methods that calculate the frontier production function of the decision- making units (firms or countries). Those that operate on the frontier are technically efficient, whereas the degree of technical inefficiency of the rest is calculated on the basis of the Euclidian distance of their input /output ratio from the frontier (Coelli, 1998). Applying DEA methodology, Färe et al., (1992) extended the work of Caves et al. (1982) and developed Malmquist productivity measures, which can be used in order to measure the productivity changes over time. Since then, the Malmquist TFP index has been applied in various studies, both in the industrial as well as the 
agricultural sector. For instance, Grifell and Sintas (1995) measured TFP change in the European textile industry, Färe et al (2001) calculated productivity growth in Taiwan's manufacturing industry, and Chen and Ali (2004) analyze the productivity in the computer industry. In the agricultural sector, the Malmquist TFP indices have become extensively used in the measure and analysis of productivity by Bureau et al. (1995), Lusigi and Thirtle (1997), Fulginity and Perrin (1997, 1998 and 1999), Rao and Coelli (1998), Arnade (1998), Chavas (2001), Suhariyanto and Thirtle (2001), Suhariyanto et al. (2001), Coelli and Rao (2003), Trueblood and Coggins (2003), Nin et al. (2003a), Nin et al. (2003b) and Ludena et al. (2005 and 2007).

As mentioned earlier, DEA can be either input-orientated or output-orientated. In the input-orientated case, the DEA method defines the frontier by seeking the maximum possible proportional reduction in input usage, with output levels held constant, for each country. While, in the output orientated case, the DEA method seeks the maximum proportional increase in output production, with input levels held fixed. The two measures provide the same technical efficiency scores when a constant returns to scale (CRS) technology applies, but are unequal when variable returns to scale (VRS) is assumed. It is worth mentioning that returns to scale properties of the technology are very important in TFP measurement. It is preferable to use a CRS technology in this study for two reasons. First, given that it is using aggregate country-level data, it does not appear to be sensible to consider a VRS technology. In addition to the above comment regarding the use of aggregate data, a second argument for the use of a CRS technology is applicable to both firm-level and aggregate data. Grifell-Tatjé and Lovell (1995) use a simple one-input, one-output example to illustrate that a Malmquist TFP index may not correctly measure TFP changes when VRS is assumed for the technology.

Hence, it is important that CRS be imposed upon any technology that is used to estimate distance functions for the calculation of a Malmquist TFP index. Otherwise, the resulting measures may not properly reflect the TFP gains or losses resulting from scale effects.

The popularity of Malmquist TFP indices is notably due to certain attractive features that: (1) It requires only data on quantities (of inputs and outputs) thus avoiding the difficult problem of measurement for fixed factors. (2) It does not require information on prices of inputs and outputs (as the Tornqvist index), in which, without this information, parametric approaches cannot be used. Both index numbers and econometric methods require price information for the calculation of costs, profits and other functions. (3) It does not require any assumptions to be made about the optimizing behaviour of economic units (in contrast to traditional index numbers). (4) It does not require econometric estimations to be made, but can be implemented using a data envelopment technique. Moreover, Malmquist TFP may not only be used in order to measure the productivity changes over time, but it can be also be further decomposed into two meaningful components, one measuring the technical change (TNCh) and the other the technical efficiency change (TECh). On the other hand, this approach is susceptible to data noise effects and to degrees of freedom problems when the sample is relatively small. 
Bushara and Mohayidin. (2009) argued that improvements in total factor productivity could occur as a result of either improvement in technical efficiency (moving closer to the production frontier) or improvements in technology (outwards shifts of the production frontier). The use of the Malmquist productivity index enabled the determination of what portion of a sector or firm productivity change was due to each of these two factors Domazlicky and Weber (1997).

Distance functions offered by Malmquist index allow one to describe a multiinput, multi-output production technology without the need to specify a behavioral objective (such as cost minimization or profit maximization). One may define input distance functions and output distance functions. An input distance function characterizes the production technology by looking at a minimal proportional contraction of the input vector, given an output vector. An output distance function considers a maximal proportional expansion of the output vector, given an input vector. However, an output distance function is only considered in detail in this paper. Anyhow, input distance functions can be defined and used in a similar manner.

\subsection{Malmquist TFP Index (Output Oriented)}

A production technology may be defined using the output set, $P(x)$, which represents the set of all output vectors, $y$, which can be produced using the input vector, $x$. That is, $P(x)=\{y: x$ can produce $y\}$

It assumes that the technology satisfies the axioms listed in Coelli et al. (1998, Ch. 3). The output distance function is defined on the output set, $P(x)$, as:

$d_{0}(x, y)=\min [\delta:(y / \delta) \in P(x)]$

The distance function, $d_{0}(x, y)$, will take a value which is less than or equal to one if the output vector, $y$, is an element of the feasible production set, $\mathrm{P}(\mathrm{x})$. Furthermore, the distance function will take a value of unity if $y$ is located on the outer boundary of the feasible production set, and will take a value greater than one if $y$ is located outside the feasible production set. This study uses DEA-like methods to calculate the distance measures.

Owing to Mahadevan (2002), Coelli and Rao (2003), Sufian (2007), Belloumi et al. (2009) and Shahabinejad and Akbari (2010), the Malmquist TFP index measures the TFP change between two data points (e.g., those of a particular country in two adjacent periods) by calculating the ratio of the distances of each data point relative to a common technology. Following Färe et al (1994), the Malmquist (output-orientated) TFP change index between period (s) (the base period) and period ( $\mathrm{t}$ ) is given by:

$$
\mathrm{m}_{0}\left(\mathrm{y}_{\mathrm{s}}, \mathrm{x}_{\mathrm{s}}, \mathrm{y}_{\mathrm{t}}, \mathrm{x}_{\mathrm{t}}\right)=\left[\frac{\mathrm{d}_{0}^{\mathrm{s}}\left(\mathrm{y}_{\mathrm{t}}, \mathrm{x}_{\mathrm{t}}\right)}{\mathrm{d}_{0}^{\mathrm{s}}\left(\mathrm{y}_{\mathrm{s}}, \mathrm{x}_{\mathrm{s}}\right)} \times \frac{\mathrm{d}_{0}^{\mathrm{t}}\left(\mathrm{y}_{\mathrm{t}}, \mathrm{x}_{\mathrm{t}}\right)}{\mathrm{d}_{0}^{\mathrm{t}}\left(\mathrm{y}_{\mathrm{s}}, \mathrm{x}_{\mathrm{s}}\right)}\right]^{1 / 2}
$$

Where, the notation $\mathrm{d}_{0}^{\mathrm{s}}\left(\mathrm{x}_{\mathrm{t}}, \mathrm{y}_{\mathrm{t}}\right)$ represents the distance from the period $(t)$ observation to the period $(s)$ technology, $(y)$ represents output and $(x)$ represents 
input. .A value of $\mathrm{m}_{0}$ greater than one will indicate positive TFP growth from period $(s)$ to period $(t)$ while a value less than one indicates a TFP decline. Note that equation 1 is, in fact, the geometric mean of two TFP indices. The first is evaluated with respect to period $(s)$ technology and the second with respect to period $(t)$ technology. An equivalent way of writing this productivity index is:

$$
\mathrm{m}_{0}\left(\mathrm{y}_{\mathrm{s}}, \mathrm{x}_{\mathrm{s}}, \mathrm{y}_{\mathrm{t}}, \mathrm{x}_{\mathrm{t}}\right)=\underbrace{\frac{\mathrm{d}_{0}^{\mathrm{t}}\left(\mathrm{y}_{\mathrm{t}}, \mathrm{x}_{\mathrm{t}}\right)}{\mathrm{d}_{0}^{\mathrm{s}}\left(\mathrm{y}_{\mathrm{s}}, \mathrm{x}_{\mathrm{s}}\right)}}[\underbrace{\frac{\mathrm{d}_{0}^{\mathrm{s}}\left(\mathrm{y}_{\mathrm{t}}, \mathrm{x}_{\mathrm{t}}\right)}{\mathrm{d}_{0}^{\mathrm{t}}(\underbrace{}_{\mathrm{t}}, \mathrm{x}_{\mathrm{t}})} \times \frac{\mathrm{d}_{0}^{\mathrm{s}}\left(\mathrm{y}_{\mathrm{s}}, \mathrm{x}_{\mathrm{s}}\right)}{\mathrm{d}_{0}^{\mathrm{t}}\left(\mathrm{y}_{\mathrm{s}}, \mathrm{x}_{\mathrm{s}}\right)}} \underbrace{1 / 2}
$$

\section{Efficiency change Technical Change}

Where, the ratio outside the square brackets measures the change in the outputoriented measure of Farrell technical efficiency between periods $(\mathrm{s})$ and $(\mathrm{t})$. That is, the efficiency change is equivalent to the ratio of the Farrell technical efficiency of period (t) to the technical efficiency in period (s). The efficiency change component measures whether production is catching up with or falling behind the production frontier and assumed that this component captures diffusion of technology related to differences in knowledge and institutional setting (Rungsuriyawiboon and Lissitsa, 2006). The remaining part of the index in equation (2) is a measure of technical change, which is the geometric mean of the shift in technology between the two periods, evaluated at xt and xs. In other words, TFP growth can be rewritten as,

\section{TFP Growth $=$ Technical Efficiency Change $\times$ Technical Change $\ldots \ldots \ldots \ldots . . .(3)$ \\ (Catching up effect) \\ (Frontier effect)}

This decomposition can be illustrated as cited in Rao et al., (2004), using the diagram in Figure 4 (after Coelli, et al., 1998), which depicts a constant returns-toscale technology involving a single input and a single output. The firm produces at the points $\mathrm{D}$ and $\mathrm{E}$ in periods $s$ and $t$ respectively. In each period, the firm is operating below the technology for that period.

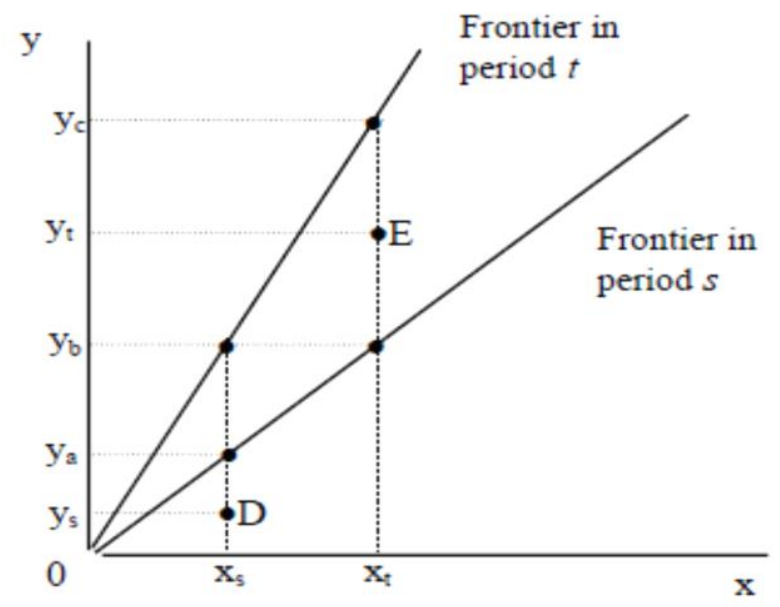

Figure (4) : Malmquist productivity indices

Source: Rao et al. (2004) 
Hence, there is technical inefficiency in both periods. Using equations 1 and 2 we obtain:

$$
\text { Efficiency Change }=\frac{y_{t} / y_{c}}{y_{s} / y_{a}} \text { \& Technical change }=\left[\frac{y_{t} / y_{b}}{y_{t} / y_{c}} \times \frac{y_{s} / y_{a}}{y_{s} / y_{b}}\right]^{1 / 2}
$$

According to Grifell-Tatj'e and Lovell (1995), the constant returns to scale (CRS) technology must however be imposed to estimate the above distance functions for the accurate calculation of a Malmquist TFP index. However, Fare et al. (1994) decomposed the catching up effect (given by technical efficiency change under the CRS technology) into 'pure' technical efficiency change and scale efficiency change. Pure efficiency depicts the effect on the ability of a firm to be more efficient due new technologies (Färe, et al., 1994). That,

\section{Technical Efficiency Change Index =}

\section{Pure Technical Efficiency Change Index $\times$ Scale Efficiency Change Index}

Following Färe et al. (1994) and given that suitable panel data are available, we can calculate the required distance measures for the Malmquist TFP index using DEA linear programm. For the i-th country, we must calculate four distance functions to measure the TFP change between two periods, $s$ and $t$. This requires solving four linear-programming (LP) problems. Färe et al. (1994) assume a constant returns-to-scale (CRS) technology in their analysis. The required LPs are

$\left[d_{0}^{t}\left(y_{t}, x_{t}\right)\right]^{-1}=\max _{\phi, \lambda} \phi \quad$ Subject to

$-\phi y_{i t}+Y_{t} \lambda \geq 0$

$x_{i t}-X_{t} \lambda \geq 0$,

$\lambda \geq 0$

$\left[d_{0}^{s}\left(y_{s}, x_{s}\right)\right]^{-1}=\max _{\phi, \lambda} \phi \quad$ Subject to

$-\phi y_{i s}+Y_{s} \lambda \geq 0$

$x_{i s}-X_{s} \lambda \geq 0$,

$\lambda \geq 0$

$\left[d_{0}^{t}\left(y_{s}, x_{s}\right)\right]^{-1}=\max _{\phi, \lambda} \phi \quad$ Subject to

$-\phi y_{i s}+Y_{t} \lambda \geq 0$,

$x_{i s}-X_{t} \lambda \geq 0$,

$\lambda \geq 0$

and

$\left[d_{0}^{s}\left(y_{t}, x_{t}\right)\right]^{-1}=\max _{\phi, \lambda} \phi \quad$ Subject to 
$-\phi y_{i t}+Y_{s} \lambda \geq 0$

$x_{i t}-X_{s} \lambda \geq 0$,

$\lambda \geq 0$

$y_{\text {it }}$ is a $M \times 1$ vector of output quantities for the i-th country in the t-th period;

$x_{i t}$ is a $K \times 1$ vector of input quantities for the i-th country in the $t$-th period;

$Y_{t}$ is a $N \times M$ matrix of output quantities for all $N$ countries in the $t$-th period;

$X_{t}$ is a $N \times K$ matrix of input quantities for all $N$ countries in the t-th period;14

$\lambda$ is a $N \times 1$ vector of weights; and

$\phi$ is a scalar.with $1 \leq \phi \leq \infty, \phi-1$ is the proportional increase in outputs that could be achieved by the i-th unit, with input quantities held constant (Nkamleu, 2004).

Note that in LPs (7) and (8), where production points are compared with technologies from different time periods, the $\varphi$ parameter need not be greater than or equal to one (as it must be when calculating standard output-orientated technical efficiencies). The data point could lie above the production frontier. This will most likely occur in LP (8) where a production point from period t is compared to technology in an earlier period, s. If technical progress has occurred, then a value of $\varphi<1$ is possible. Note that it could also possibly occur in LP (7) if technical regress has occurred, but this is less likely. However, more detailed reviews of DEA methodology could be reviewed in Seiford and Thrall (1990), Lovell (1993), Ali and Seiford (1993). Lovell (1994), Charnes et al. (1995) and Seiford (1996)

However, Total factor productivity (TFP) is the ratio of total output (crop and livestock products) to total production inputs (land, labor, capital, and materials). An increase in TFP implies that more output is being produced from a constant amount of resources used in the production process.

In the long run, TFP is the main driver of growth in agriculture and can be affected by policies and investment. Partial factor productivity (PFP) measures, such as labor and land productivity, are often used to measure agriculturalproduction performance because they are easy to estimate. These measures of productivity normally show higher rates of growth than TFP because growth in land and labor productivity could result from more intensive use of inputs, including fertilizer and machinery, rather than TFP increase. If productivity increases without the addition of more inputs, then the only source of growth is TFP.

\section{ESTIMATION PROCESS}

In line with Coelli and Rao (2003), Belloumi and Matoussi (2009), Shahabinejad and Akbari (2010) and other studies, the study estimates the Malmquist indexes of efficiency and total factor productivity employing a panel data. The analysis uses two outputs (crops and livestock production) and six inputs (land, tractors, labor, fertilizer consumption, animal livestock and irrigation).

\subsection{Output Series}

Agricultural output for crops and livestock is expressed as (constant 2004-2006) "international dollars".

\subsection{Input Series}

As mentioned earlier, the study considers only six input variables. Details of these variables are given below: 


\subsubsection{Land}

This variable covers the number of hectares of arable and permanent cropland 5.2.2 Tractors

This variable is measured as total number of tractors used in agriculture (excluding garden tractors).

\subsubsection{Labor}

This variable is measured as the total economically active agricultural population.

\subsubsection{Fertilizer}

Following other studies that applied DEA such as Hayami and Ruttan (1970), Fulginiti and Perrin (1997), Shahabinejad and Akbari (2010), the study uses consumption of Nitrogen $(\mathrm{N})$, Potassium $\left(\mathrm{K}_{2} \mathrm{O}\right)$ and Phosphate $\left(\mathrm{P}_{2} \mathrm{O}_{2}\right)$ in metric tons.

\subsubsection{Livestock}

The livestock input variable is calculated by the animal-equivalent of five categories of animals. The considered categories are buffaloes, cattle, sheep, goats, horses, camels, chicken and ducks. Numbers of these animals are converted into animal equivalents using conversion factors adopted by Coelli and Rao (2003), El-Kholei et al. (2008) and Shahabinejad and Akbari (2010) as follows: 1.0 for buffalo and cattle; 0.1 for sheep and goats, 1 for horses, 1.1 for camels, 0.01 for chickens and ducks.

\subsubsection{Irrigation}

The study employs the area under irrigation as a proxy for the capital infrastructure associated with the irrigation of farmlands.

After gathering the suitable panel data for the above-mentioned outputs and inputs variables and assuming constant returns to scale (CRS) as mentioned earlier, then the required distance measures for the Malmquist TFP index could be calculated using DEA-like linear programs. However, a number of N×(3T-2) LP's would be solved. In this study $\mathrm{N}=$ nine countries and $\mathrm{T}=$ thirty-three periods $(1980-2012)$, this requires the solving of $[9 \times(3 \times 33-2)]=873$ LP's.

\section{RESULTS}

Conceptually, a country can increase its agricultural productivity by two different ways. One way is to improve efficiency change through the "best practice" by increasing the diffusion of technology, and the other way is to promote technical change, through importation and adaptation of new technology. Of course, a combination of both also increases agricultural productivity.

There is massive computer output on efficiency scores for each country in each year to illustrate. The results have measures of technical efficiency change; technical change and TFP change for each country in each pair of adjacent years (see Appendixes 1 to 5). However, the paper would be selective in what results to present.

An output-orientated technical efficiency level shows the ratio of each country's actual output in relation to what is feasible (given the available technology in that period). Technology in each period, identified using the DEA technique, is a piece-wise linear envelopment of all the observed points in the multi 
output and multi-input Euclidean space. The countries that determine the technology frontier are known as the "peers" or best-performing countries. Peer countries have a technical efficiency score of one and usually there are several peers in each year.

Results for technical efficiency scores and their averages in 1980s, 1990s and 2000s are shown in Table 1. They reveal that, except for Morocco, Yemen and Tunisia, all sampled countries are technically efficient all over the three periods. However, 1980-2012 average score shows that Morocco and Iraq achieved the highest level in mean technical efficiency reaching 1.008 and 1.004 respectively; whereas, all other sampled countries achieved unity meaning that there was no change in efficiency over those periods. (see Figure 5). In general, the results depict that all of the sampled countries reached frontier technical efficiency throughout the three successive periods. However, the sampled countries achieved the highest level in mean technical efficiency (1.002) during the first and second periods. Meanwhile, producing $99 \%$ during the second period of the output that could be potentially produced using the observed input quantities.

Telleria and Hassan (2001) argued that Arnade (1998) gives a possible explanation for this particular result. He argues that when there are no apparent changes in efficiency levels (i.e., when Effch =1), in the case of developing countries in which extraordinarily low levels of inputs are used, then this may be interpreted as either no change, or a slight improvement, in the use of outdated technology.

Table (1): Technical Efficiency Change (Effch) for Sampled Arab Countries during the period (1980-2012).

\begin{tabular}{lcccc}
\hline & $\begin{array}{c}\mathbf{1 9 8 0 - 1 9 9 0} \\
\mathbf{1}^{\text {st }} \text { Period }\end{array}$ & $\begin{array}{c}\mathbf{1 9 9 1 - 2 0 0 0} \\
\mathbf{2}^{\text {nd }} \text { Period }\end{array}$ & $\begin{array}{c}\mathbf{2 0 0 1 - 2 0 1 2} \\
\mathbf{3}^{\text {rd }} \text { Period }\end{array}$ & $\begin{array}{c}\mathbf{1 9 8 0 - 2 0 1 2} \\
\text { Average }\end{array}$ \\
\hline Morocco & 1.027 & 0.976 & 1.019 & 1.008 \\
Iraq & 1.002 & 1.011 & 1.000 & 1.004 \\
Yemen & 0.993 & 1.007 & 1.000 & 1.000 \\
Algeria & 1.000 & 1.000 & 1.000 & 1.000 \\
Egypt & 1.000 & 1.000 & 1.000 & 1.000 \\
Jordan & 1.000 & 1.000 & 1.000 & 1.000 \\
Sudan & 1.000 & 1.000 & 1.000 & 1.000 \\
Syria & 1.000 & 1.000 & 1.000 & 1.000 \\
Tunisia & 1.000 & 0.998 & 1.001 & 1.000 \\
Average & 1.002 & 0.999 & 1.002 & Average \\
\hline
\end{tabular}

Source: Author calculation via DEA analysis results (all figures are geometric mean) 


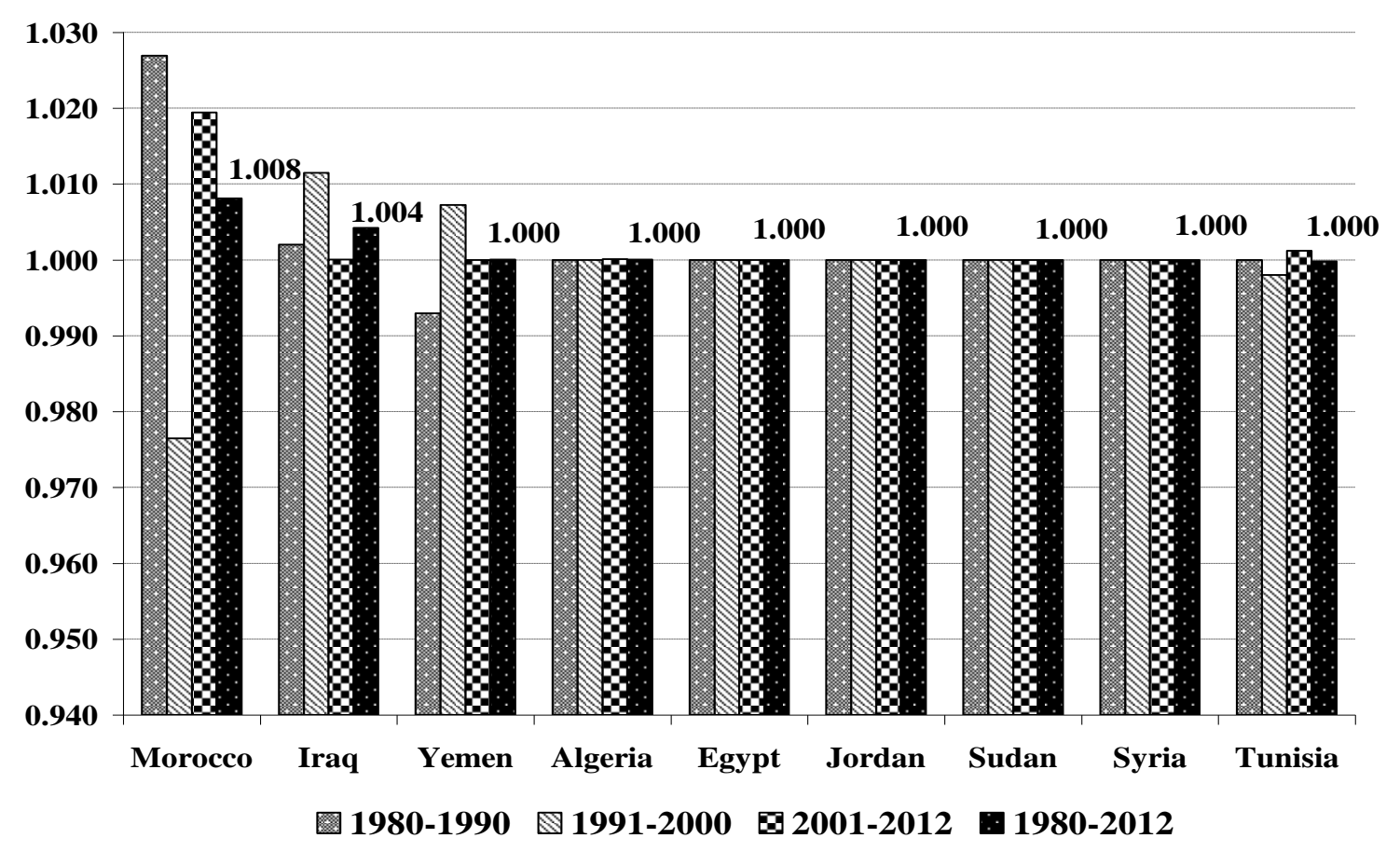

Figure (5): Technical Efficiency Change during the period 1980-90, 1991-2000, 2001-2012 and 1980-2012 (on average)

Source: Appendix 1

As cited by Belloumi et al (2009), this average technical efficiency change gives us information only on the "catch-up" part of the productivity (mentioned in Equation 3). In fact, a country will have a positive efficiency change over time if it is catching up. The degree of catching up or the efficiency change can be related to institutional factors, as well as domestic and trade policies of specific countries. TFP change can also appear in the form of technical change (or frontier-shift). In other words, Movements in total factor productivity are measured using the Malmquist productivity index. Using the output-oriented approach, the index provides a measure of how much more can be produced using observed input data - at the technologies observed at two different points of time. The Malmquist productivity index can be decomposed into output increases due to efficiency change and those due to shifts in frontier technology.

The Malmquist index measures year-to-year changes in productivity. These indices as well as their associated efficiencies and technical change components for considered countries in the analysis are presented in Appendixes 1, 2 and 3.

Some salient features of these findings are summarized in Table 2. It shows the annual mean technical efficiency change, technical change and TFP change, averaged throughtout the period 1980-2012. The average (across all countries) growth in TFP is $1.2 \%$, which is due to $0.2 \%$ growth in efficiency change and $1 \%$ in technical change.

In general, except for Iraq (for some extent) and Syria, all the sampled countries showed to be innovative and efficient at the same time. The country with 
the highest TFP growth is Jordan, with an impressive $3.7 \%$ average annual growth in TFP, mainly attributable to technical change indicating the highest agricultural productivity relative to the other countries considered in the study. Similar results could be seen for Yemen and Algeria (about 3\% each), Egypt (2\%), Sudan (0.8\%), Tunisia and Iraq (0.4\%). This may reflect improvements in the agricultural extension services in those countries. Whereas, Morocco is the only Arab country where its TFP growth $(2.5 \%)$, is largely attributable to both efficiency change and technical change accounting $0.8 \%$ and $1.6 \%$ respectively (see Table 2 and Figure $6)$.

\section{Table (2): Technical Efficiency Change, Technical Change and Total Factor Productivity for Sampled Arab Countries during the period (1980- 2012)}

\begin{tabular}{lccc}
\hline & $\begin{array}{c}\text { Efficiency Change } \\
\text { (Effch) }\end{array}$ & $\begin{array}{c}\text { Technical Change } \\
\text { (Techch) }\end{array}$ & $\begin{array}{c}\text { TFP Change } \\
\text { (TFPch) }\end{array}$ \\
\hline Algeria & 1.000 & 1.030 & 1.030 \\
Egypt & 1.000 & 1.020 & 1.020 \\
Iraq & 1.004 & 0.999 & 1.003 \\
Jordan & 1.000 & 1.037 & 1.037 \\
Morocco & 1.008 & 1.016 & 1.025 \\
Sudan & 1.000 & 1.008 & 1.008 \\
Syria & 1.000 & 0.951 & 0.951 \\
Tunisia & 1.000 & 1.004 & 1.004 \\
Yemen & 1.000 & 1.031 & 1.031 \\
Geo.Mean & 1.002 & 1.010 & 1.012 \\
\hline
\end{tabular}

Source: Appendixes 1, 2 and 3

On the other hand, Iraq's TFP growth of $0.3 \%$ is mainly attributable to efficiency change. Meanwhile, Syria showed the lowest TFP index (0.951) Techch and TFP change are both negative $(-4.9 \%$ and $-4.9 \%$ respectively), this is presumably due to political tension and uprising riots that resulted lack of improvements as the annual average Techch fell from 1.005 during the period 1980-2007 to only 0.707 during the period 2008-2012 (on average). 


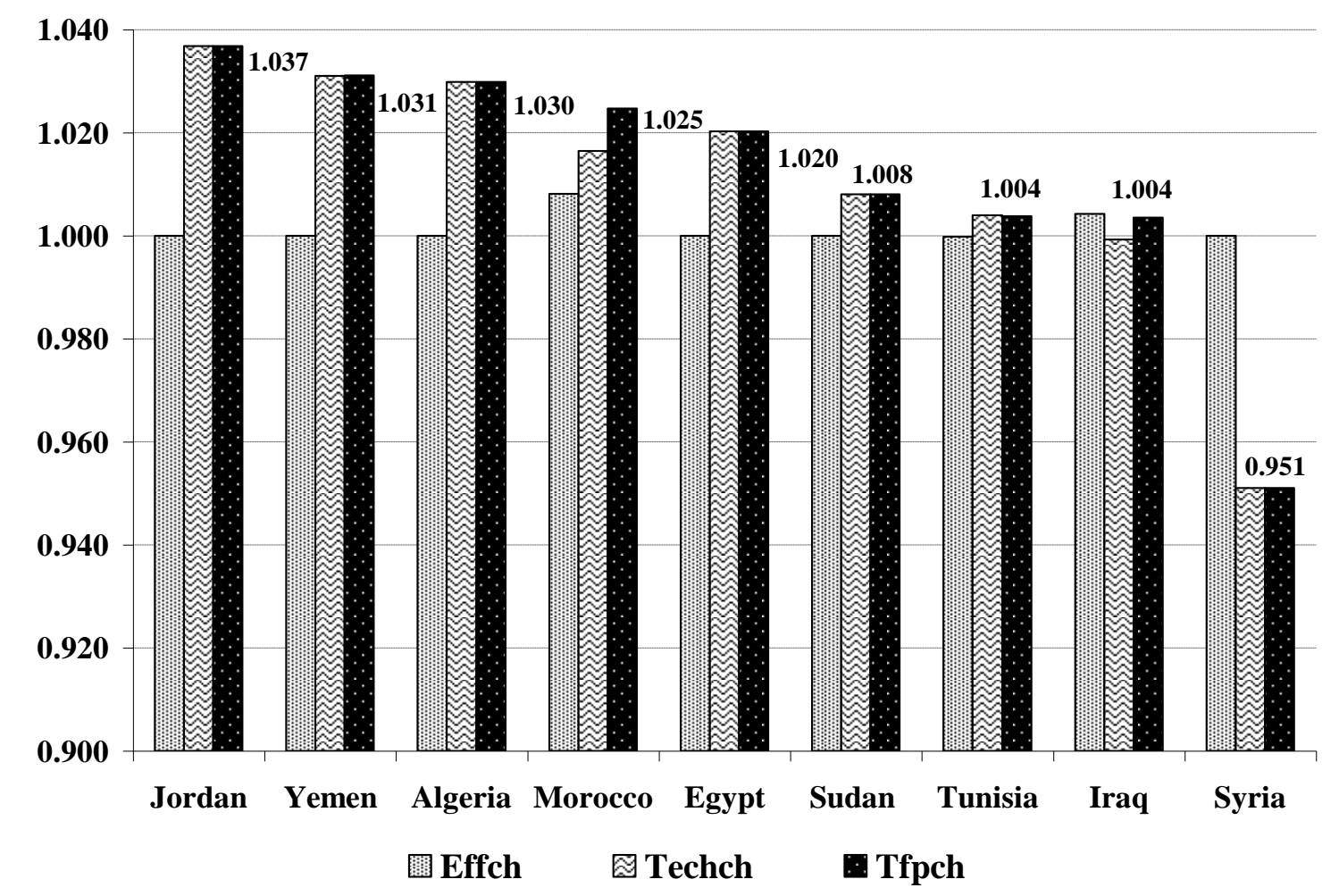

Figure (6): Effch, Techch and TFPch Results during the period (1980-2012)

Source: Appendixes 1, 2 and 3

In order to trace the development of TFP index results and its components, the study disaggregated the study period $1980-2012$ into six successive periods 1980-85, 1986-90, 1991-95, 1996-2000, 2001-2005 and 2006-1012 shown in Figures 7, 7A and 7B.

In general, except for Morocco and to a mere extent Egypt, all TFP results fell in last period (2006-2012) compared to majority of previous periods with various levels (see Figure 7) This decline is mirrored by the decline in technological change for the same periods (see Figure 7A). Moreover, technical efficiency results showed stagnation of unity all over the study period (1980-2012) in countries such as Egypt, Jordan, Sudan and Syria, whereas, Morocco achieved a significant increase throughout the last three periods (1996-2000), (2001-2005) and (20062012) from 0.965 to 0.995 and further to 1.037 respectively (see Figure 7B). Reporting stagnant technical change (as achieved by majority of sampled countries) does not necessarily mean that no technical change has occurred at all. It may have occurred but at very low rates compared with those occurring in the best practice countries, considering that each country's technical change performance was measured only relative to the best countries in the sample. 


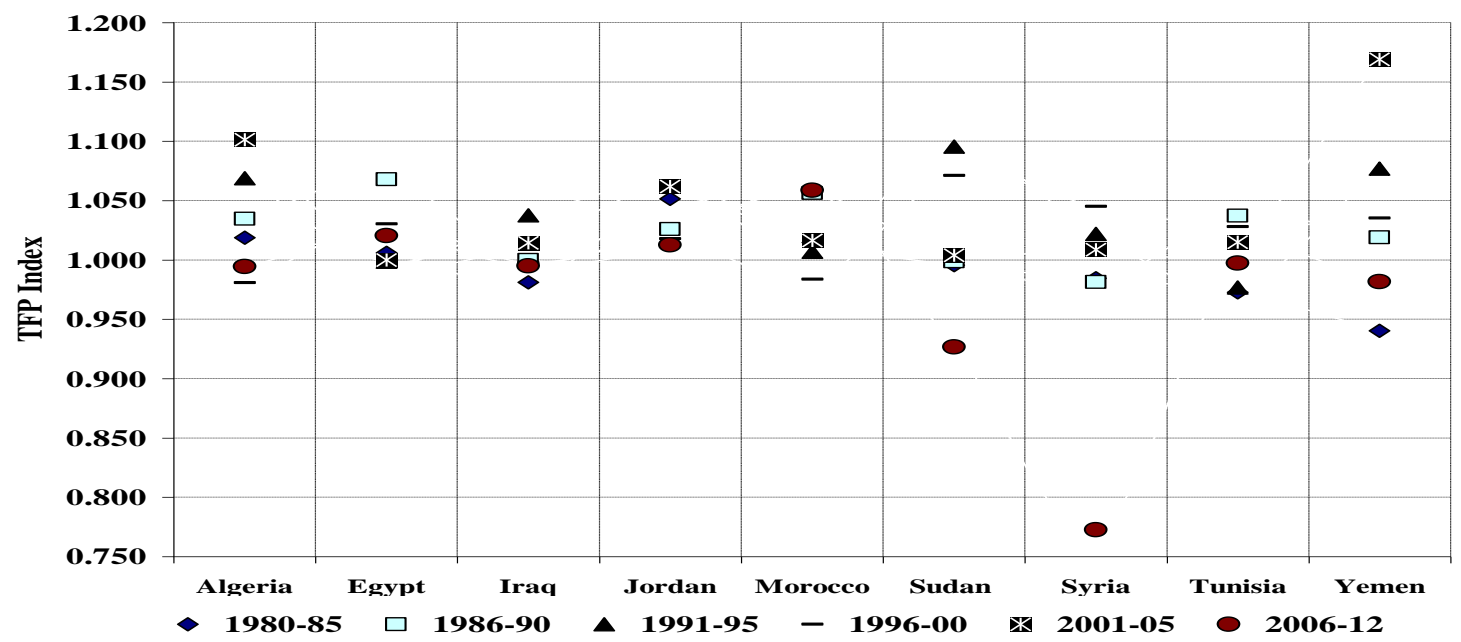

Figure (7): TFPch Results during the Disaggregated period (1980-2012)

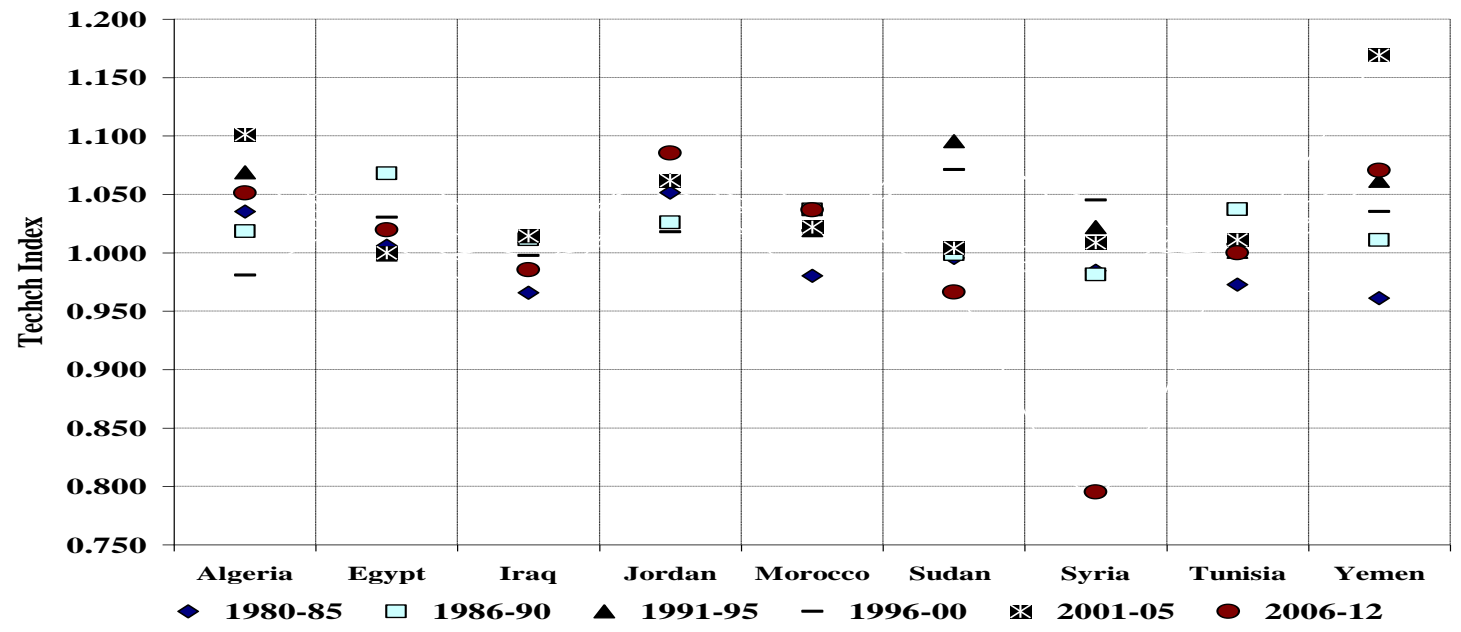

Figure (7A): Techch Results during the Disaggregated period (1980-2012) 


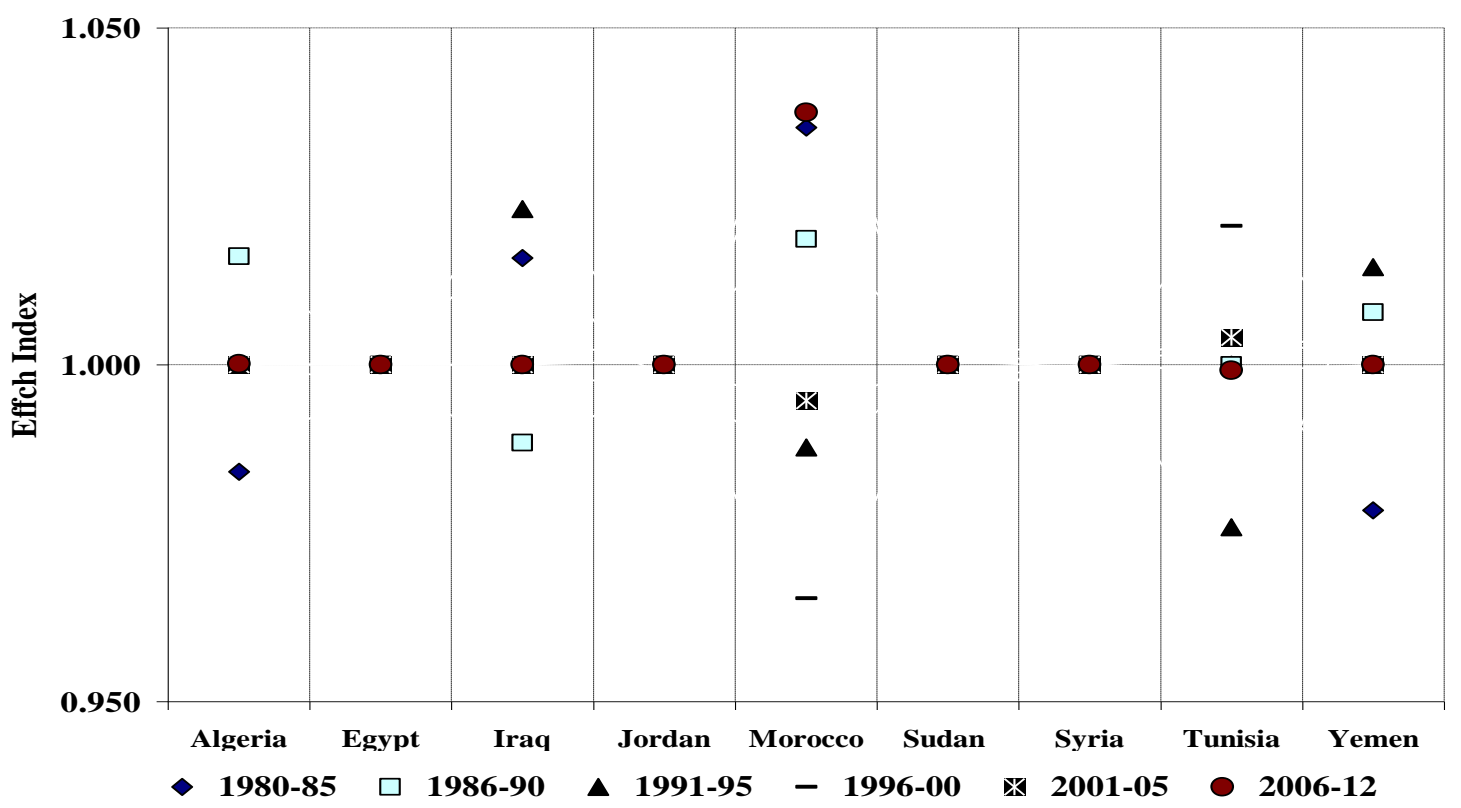

Figure (7B): Effch Results during the Disaggregated period (1980-2012)

Source: Appendix 3

However, it fell during the last two periods compared to previous decade in countries such as Yemen, Tunisia and Iraq. These poor results for TFP and its components during the last period, are presumably due to lack of agricultural infrastructure investment, the political tension and riots engaged to what so called "Arabian Spring"

As mentioned earlier, Morocco reached TFP growth rate of $2.5 \%$ during the whole period 1980 - 2012. TFP growth estimates for the last three decades are, $3.5 \%,-0.5 \%$ and $4.1 \%$ respectively. Fortunately, the positive increase offsets the earlier losses. Agriculture TFP growth in Morocco needs to be higher because even agriculture accounts for about $14 \%$ of the country's total GDP, it employs nearly $36 \%$ of the local labor force and drives the country's economic growth. Morocco is probably the most volatile grain production country in the world.

Egypt shows a $2 \%$ average growth in TFP throughout the study period (19802012 ), which is due to $2 \%$ growth in technical change. TFP growth in Egypt fell from $3.6 \%$ in the 1980 s to $1.4 \%$ and further to $1.2 \%$ during the 1990 s and 2000 s respectively. The same pattern could be seen for Jordan.

Sudan and Syria reached their highest TFP during the 1990s that estimated at average growth $8.3 \%$ and $3.4 \%$ respectively; however, it fell during the 2000 s to nearly $-4.2 \%$ and $-3.7 \%$ respectively.

In short, the above findings allow the ranking of the more and less productive countries, and have useful agricultural policy implications 


\section{CONCLUSION}

As argued by Telleria and Hassan (2011), there are two fundamental approaches used to measure agricultural productivity, frequently known as parametric and non-parametric approaches. In the past, the parametric approach has widely used the Laspeyres Index (which uses base year prices and current quantities, i.e., base-period weights) to measure agricultural productivity through value added per unit of input. However, the Theil-Tornqvist Index, which uses prices from both the base period and the comparison period, is preferred to the Laspeyres Index because it does not require the unrealistic assumption that all inputs are perfect substitutes in production. However, the main problem with the Theil-Tornqvist Index is that it does not satisfy transitivity conditions, making it inapplicable for comparisons involving a set of three or more countries. It is observed that index numbers use local currencies (such as dollars) to aggregate heterogeneous outputs and inputs, but such currencies are not adjusted to account for changes in the value of the currency over time, thus limiting the understanding of trends in agricultural productivity. Lately, The Malmquist Index uses the nonparametric method, initiated as the Data Envelopment Analysis (DEA) by Charnes, Cooper and Rhodes (1978), builds on the individual firm evaluations of Farrell (1957) applying linear programming to estimate an empirical production technology frontier for the first time.

This paper has investigated the level and growth pattern in agricultural productivity in Arab countries whose agricultural sector plays a considerable role in the economy. Nine contries have been included in the analysis namely are Algeria, Egypt, Iraq, Jordan, Morocco, Sudan, Syria, Tunisia and Yemen. For this purpose, the sequential Malmquist approach was employed in order to calculate TFP indices. Results show that the most productive countries were Jordan, Yemen, Algeria, Morocco, Egypt, Sudan, Tunisia and Iraq. Finally, the agricultural sectors of and Syria was, in comparison, the least productive.

Technical efficiency change has been the main source of achievement of high levels of total factor productivity during the reference period. It is obvious that in all countries technical change is more than efficiency change. In other words, technical change is the main source of total factor productivity fluctuation over time, because the technical change component has had more fluctuation, rather than technical efficiency change. This average technical efficiency change gives us information only on the "catch-up" part of the productivity issue. In fact, a country will have a positive efficiency change over time if it is catching up. The degree of catching up or the efficiency change can be related to institutional factors, domestic and trade policies of specific countries.

The TFP results for Iraq and Syria (i.e., Techch smaller than Effch scores) imply that policy actions should focus more on accelerating the rate of Techch (agricultural innovation) than the rate of Effch (technology diffusion). The opposite applies to the case of Algeria, Egypt, Jordan, Morocco, Sudan, Tunisia and Yemen where Effch scores smaller than Techch scores, indicating the need for 
strengthening policy actions focusing on accelerating the rate of agricultural services throughout the country.

It is a matter of serious concern that the overall contribution of technical change is greater than that of efficiency change to overall productivity changes in all the studied countries. This implies huge potential increase in production even with existing technology. It is important to reverse efficiency stagnation that appears in majority of countries and achieve a faster and large scale diffusion of technical innovations across regions.

In line with Telleria and Hassan (2011), the fact that Techch has been the main driving force of TPF indicates that investing in agricultural research is the main lever to increase productivity. Yet it must be acknowledged that low values of Effch usually indicate that long time lags between agricultural research investments and productivity response exist. This indicates that spending on agricultural research must be accompanied by agricultural extension programmes that not only contribute to broaden the use of new technology, but to agricultural capital formation as well.

Finally, government should take some necessary steps to focus on improving crop productivity and to provide farmers timely and extensive services and support so that crop farming can be made more efficient.

\section{REFERENCES}

Aigner, D., Lovell, C. A. K. and Schmidt, P. (1977). Formulation and estimation of stochastic frontier production function models. Journal of Econometrics, 6(1), 21-37. doi: 10.1016/0304-4076(77)90052-5

Ali, A.I. and Seiford L.M. (1993). "The Mathematical Programming Approach to Efficiency Analysis" in The Measurement of Productive Efficiency: Techniques and Applications", (Eds) H. O. Fried, C. A. K. Lovell and S. S. Schmidt, Oxford University Press, New York, 120-159.

Amara, N., Traoré, N., Landry, R., and Remain, R. (1999). Technical Efficiency and Farmers' Attitudes toward Technological Innovation: The Case of the Potato Farmers in Quebec. Canadian Journal of Agricultural Economics/Revue canadienne d'agroeconomie, 47(1), 31-43. doi: 10.1111/j.1744-7976.1999.tb00214.x

Arab Organization for Agricultural Development (AOAD), on line statistics, www.aoad.org

Arnade, C. (1998). "Using a programming approach to measure international agricultural efficiency and productivity". Journal of Agricultural Economics 49: 67-84.

Banker, R. D., Charnes, A. and Cooper, W. W. (1984). Some Models for Estimating Technical and Scale Inefficiencies in Data Envelopment Analysis. Management Science, 30(9), 1078-1092.

Belloumi, M and Matoussi, M S., (2009). "Measuring agricultural productivity growth in MENA countries". Journal of Development and Agricultural Economics Vol. 1(4), 103-113. 
Bravo-Ureta, B., Solís, D., Moreira López, V., Maripani, J., Thiam, A., and Rivas, T. (2007). "Technical efficiency in farming: a meta-regression analysis". Journal of Productivity Analysis, 27(1), 57-72. doi: 10.1007/s11123-006-0025-3

Bureau, C., Färe R., and Grosskopf S. (1995). "A comparison of three nonparametric measures of productivity growth in European and United States Agriculture". Journal of Agricultural Economics 45: 309-26.

Bushara, M. and Mohayidin, M. G. (2009). "Catching-up and Technological Change in Malaysian Oil and Fat Industry: A Nonparametric Frontier Analysis". University Of Gezira, Sudan, Gezira Journal of Engineering and Applied Sciences. Vol.2 P (2).

Charnes, A., Cooper, W. and Rhodes, E. (1978). Measuring efficiency of decision-making units. European Journal of Operation Research, 6, 429444.

Charnes, Al, W.W. Cooper, A.Y. Lewin and L.M. Seiford (1995). "Data Envelope Analysis: Theory, Methodology and Applications", Kluwer

Caves, D.W., Christensen, L.R., and Diewert, W.E. (1982). The economic theory of index numbers and the measurement of input, output and productivity. Econometric, 50(6), 1414- 1939.

Chavas, J. P. (2001). An international analysis of agricultural productivity. In Agricultural investment and productivity in developing countries, edited by $\mathrm{L}$. Zepeda. Rome: Food and Agriculture Organization.

Chen, Y., Ali, A.I. (2004). "DEA Malmquist productivity measure: New insights with an application to computer industry". European Journal of Operational Research , 159 (1), 239- 249

Coelli, T.J., Prasada Rao D.S. and Battese G.E. (1998). "An Introduction to Efficiency and Productivity Analysis", Kluwer Academic Publishers, Boston.

Coelli, T. J., and Rao , D.S (2003). "Total factor productivity growth in agriculture: a Malmquist index analysis of 193 countries. Centre for Efficiency and Productivity Analysis". School of Economics. University of Queensland. St Lucia. Australia. Working paper 02/2003. 30 pages

Domazlicky, B. R., William L. Weber. (1997). "Total Factor Productivity in the Contiguous United States, 1977 - 1986". Journal of Regional Science 37 (2): 213-233.

El-Kholei, A., Abo-Zeid, A., and Abo-Saad, H.(2008). "Further Evidence on Agricultural Output and Rural-Urban Migration Linkages in Egypt: Drives and Policy Implications". Alexandria Journal of Agricultural Research, , 53(2): 13-21.

FAO, Food and Agriculture Organization, online statistics.

Farrel, M. (1957). "The Measurement of Productive Efficiency" Journal of the Royal Statistical Society. Series A, general, 120(3): 253-281.

Färe, R., Grosskopf, S., Lindgren B.and Roos P. (1992). Productivity change in Swedish pharmacies 1980- 1989: A non- parametric Malmquist approach. Journal of Productivity Analysis, 3, 85- 102.

Färe, R., S. Grosskof, and C. A. K. Lovell (1994). "Production Frontiers", Cambridge University Press. 
Färe, R., Grosskopf, S., Norris, M. and Zhang, Z. (1994). "Productivity growth, technical progress and efficiency change in Indus trialized countries." American Economic Review 84, 66--83.

Färe, R. Grosskopf, S.and Lee, W. (2001). Productivity and technical change: The case of Taiwan. Applied Economics, 33: 1911- 1925.

Fulginiti, L.E.and Perrin, R.K. (1997). "LDC Agriculture: Nonparametric Malmquist Productivity Index". Journal of Development Economics , 53: 373- 390.

Fulginiti, L. and Perrin, R.K. (1998). "Agricultural productivity in developing countries". Agricultural Economics, 19 (1- 2): 45- 51.

Fulginiti, L. and Perrin, R.K. (1999). "Have price policies damaged LDC agricultural productivity?" Contemporary Economic Policy 17: 469-75.

Galanopoulos, K., Lindberg, E., Surry, Y., and Mattas, K., (2006). Agricultural situation in the Mediterranean and Tests of Convergence Among Countries. Paper prepared for presentation at the $98^{\text {th }}$ EAAE Seminar 'Marketing Dynamics within the Global Trading System: New Perspectives', Chania, Crete, Greece as in: 29 June -2 July.

Garibaldi, L. A., Aizen, M. A., Klein, A. M., Cunningham, S. A., and Harder, L. D. (2011). "Global growth and stability of agricultural yield decrease with pollinator dependence". Proceedings of the National Academy of Sciences, 108(14), 5909-5914. doi: 10.1073/pnas.1012431108

Grifell, E. and J. López Sintas (1995). Total Factor productivity: technical efficiency, bias and technical change in the European textile- clothing industry, 1980- 1989. Management Report series No 210. Erasmus University. Rotterdam School of Management. Rotterdam. March 1995.

Grifell-Tatj'e, E. and Lovell, C. A. K.(1995). "A Note on the Malmquist Productivity Index". Economics Letters, 47:169-175.

Gutierrez, L. (2000). "Convergence in US and EU agriculture". European Review of Agricultural Economics, 27(2): 187- 206.

Hayami, Y.and Ruttan, V.W. (1970). Agricultural Productivity Differences Y among Countries. American Economic Review, vol. 60(5), 895- 911.

Lovell, C A K. (1993). "Production frontiers and productive efficiency", in The Measurement of Productive Efficiency: Techniques and Applications", (Eds) H. O. Fried, C. A. K. Lovell and S. S. Schmidt, Oxford University Press, Oxford, UK.

Lovell, C. A. K. (1994). "Linear Programming Approaches to The Measurement and Analysis of Productive Efficiency" Top, 2, 175-248

Lusigi, A. and C. Thirtle (1997). "Total factor productivity and the effects of R\&D in African agriculture". Journal of International Development, 9: 529-38.

Ludena, C. E., Hertel, T. W., Preckel, P. V. Foster, K.and Nin- Pratt, A. (2005). "Technological change and convergence in crops and livestock production" Contributed paper presented for the 8th Annual Conference on Global Economic Analysis, Lübeck, Germany, June 9- 11, 2005.

Ludena, C. E., Hertel, T. W., Preckel, P. V., Foster, K. and Nin, A. (2007). "Productivity growth and convergence in crop, ruminant, and non-ruminant 
production: Measurement and forecasts". Agricultural Economics 37 (1): 117

Mahadevan, R. (2002). "A DEA Approach to Understanding the Productivity Growth of Malaysia's Manufacturing Industries" Asia Pacific Journal of Management, 19(4):587-600

McErlean, S.and Wu, Z. (2003). "Regional agricultural labour productivity convergence in China". Food Policy, 28, 237- 252.

Mukherjee, A.N.and Kuroda, Y. (2003). "Productivity growth in Indian agriculture: Is there evidence of convergence across states?" Agricultural Economics, 29, 43- 53.

Nin, A., Arndt, C. and Preckel P. (2003a). "Is agricultural productivity in developing countries really shrinking? New evidence using a modified nonparametric approach". Journal of Development Economics ,71: 395-415.

Nin, A., Arndt, C. Hertel, T. and Preckel, P. (2003b). "Bridging the gap between partial and total factor productivity measures using directional distance functions". American Journal of Agricultural Economics, 85 (4): 937-51.

Nin, A., Yu, B. and Fan, S. (2008). "Developing Countries and Total Factor Productivity Growth in Agriculture: New Evidence Using a Malmquist Index with Constrained Implicit Shadow Prices" Paper presented at Presented at the 11th Annual Conference on Global Economic Analysis, Helsinki, Finland

Nkamleu GB (2004). Productivity Growth, Technical Progress and Efficiency Change in African Agriculture. Afr Dev. Rev. 16: 203-222.

Onjala. O. J. (2002). "Total factor productivity in Kenya: The links with trade Policy", AERC Research Paper118, African Economic Research Consortium, Nairobi.

Rao, P. and Coelli, T. J. (1998). "Catch-up and convergence in global agricultural productivity, 1980-1995". CEPA Working Papers, No. 4/98, Department of Econometrics, University of New England, Armidale, p. 25.

Rao, P. and Alauddin, M. (2004). "Agricultural productivity growth, employment and poverty in developing countries, 1970-2000". Centre for Efficiency and Productivity Analysis (CEPA), Employment Strategy Paper no. 9/2004, School of Economics, University of Queensland, Brisbane, Australia.

Rungsuriyawiboon, S and Lissitsa, A. (2006). "Agricultural Productivity Growth in The European union and Transition Countries". Leibniz Institute of Agricultural Development in Central and Eastern Europe. Discussion Paper No.94

Seiford, L. M. and Thrall, R. M. (1990). "Recent Development in DEA: The Mathematical Programming Approach to Frontier Analysis". Journal of Econometrics

Seiford, L.M. (1996). "Data Envelope Analysis: The Evolution of the State of the Art (1978-1995)". Journal of Productivity Analysis, 7: 99-138

Shahabinejad, V and Akbari, A (2010). "Measuringagricultural productivity growth in Developing Eight" Journal of Development and Agricultural Economics, 2(9): 326-332.

Sufian, F. (2007). "The efficiency of Islamic banking industry in Malaysia: Foreign vs domestic banks" Humanomics, 23( 3): 174 - 192 
Suhariyanto, K., Lusigi, A. and Thirtle, C. (2001). "Productivity growth and convergence in Asian and African agriculture". In Asia and Africa in comparative economic perspective, edited by $\mathrm{P}$. Lawrence and $\mathrm{C}$. Thirtle, 258-74. London: Palgrave.

Suhariyanto, K., and Thirtle, C. (2001). "Asian agricultural productivity and convergence". Journal of Agricultural Economics ,52: 96-110.

Telleria, R. and Hassan, A. (2011). "Agricultural Productivity in the WANA Region", the Journal of Comparative Asian Development, 10(1)

Thiam, A., Bravo-Ureta, B. E., and Rivas, T. E. (2001). "Technical efficiency in developing country agriculture: a meta-analysis". Agricultural Economics, 25(2-3), 235-243. doi: 10.1111/j.1574-0862.2001.tb00204.x

Trueblood, M. A. and Coggins, J. (2003). "Intercountry agricultural efficiency and productivity: A Malmquist index approach". Mimeo. World Bank, Washington, D.C.

Wiebe, K., Soule, M., Narrod, C.and Breneman, V. (2000). "Resource quality and agricultural productivity: a multi - country comparison". Selected paper for presentation at the annual meeting of the American Association of Agricultural Economists. Tampa, Florida, July 312000.

World Bank, World Development Indicators, online statistics. 
J. Adv. Agric. Res. (Fac. Agric. Saba Basha)

\section{APPENDIXES:}

Appendix (1): Technical Efficiency Change Results during 1980-2012

\begin{tabular}{|c|c|c|c|c|c|c|c|c|c|c|}
\hline Effch & Algeria & Egypt & Iraq & Jordan & Morocco & Sudan & Syria & Tunisia & Yemen & Average \\
\hline $1981^{*}$ & 1.000 & 1.000 & 1.008 & 1.000 & 1.038 & 1.000 & 1.000 & 1.000 & 1.000 & 1.005 \\
\hline 1982 & 1.000 & 1.000 & 1.135 & 1.000 & 1.254 & 1.000 & 1.000 & 0.823 & 1.000 & 1.018 \\
\hline 1983 & 1.000 & 1.000 & 1.000 & 1.000 & 0.894 & 1.000 & 1.000 & 1.215 & 0.912 & 0.999 \\
\hline 1984 & 1.000 & 1.000 & 0.830 & 1.000 & 1.107 & 1.000 & 1.000 & 1.000 & 1.097 & 1.001 \\
\hline 1985 & 0.923 & 1.000 & 1.139 & 1.000 & 0.923 & 1.000 & 1.000 & 1.000 & 0.896 & 0.985 \\
\hline 1986 & 1.083 & 1.000 & 0.904 & 1.000 & 1.097 & 1.000 & 1.000 & 1.000 & 1.098 & 1.018 \\
\hline 1987 & 1.000 & 1.000 & 1.009 & 1.000 & 0.999 & 1.000 & 1.000 & 1.000 & 1.017 & 1.003 \\
\hline 1988 & 1.000 & 1.000 & 0.952 & 1.000 & 1.001 & 1.000 & 1.000 & 0.850 & 1.000 & 0.977 \\
\hline 1989 & 1.000 & 1.000 & 1.218 & 1.000 & 1.000 & 1.000 & 1.000 & 1.176 & 1.000 & 1.041 \\
\hline 1990 & 1.000 & 1.000 & 0.892 & 1.000 & 1.000 & 1.000 & 1.000 & 1.000 & 0.931 & 0.980 \\
\hline 1991 & 1.000 & 1.000 & 1.121 & 1.000 & 1.000 & 1.000 & 1.000 & 1.000 & 0.898 & 1.001 \\
\hline 1992 & 1.000 & 1.000 & 1.000 & 1.000 & 1.000 & 1.000 & 1.000 & 1.000 & 1.193 & 1.020 \\
\hline 1993 & 0.966 & 1.000 & 1.000 & 1.000 & 1.000 & 1.000 & 1.000 & 1.000 & 1.003 & 0.996 \\
\hline 1994 & 1.004 & 1.000 & 1.000 & 1.000 & 0.997 & 1.000 & 1.000 & 0.878 & 1.000 & 0.986 \\
\hline 1995 & 1.031 & 1.000 & 1.000 & 1.000 & 0.943 & 1.000 & 1.000 & 1.008 & 1.000 & 0.998 \\
\hline 1996 & 1.000 & 1.000 & 1.000 & 1.000 & 1.064 & 1.000 & 1.000 & 1.130 & 1.000 & 1.021 \\
\hline 1997 & 1.000 & 1.000 & 1.000 & 1.000 & 0.865 & 1.000 & 1.000 & 1.000 & 1.000 & 0.984 \\
\hline 1998 & 0.993 & 1.000 & 1.000 & 1.000 & 1.128 & 1.000 & 1.000 & 1.000 & 1.000 & 1.013 \\
\hline 1999 & 1.007 & 1.000 & 1.000 & 1.000 & 0.841 & 1.000 & 1.000 & 1.000 & 1.000 & 0.982 \\
\hline 2000 & 1.000 & 1.000 & 1.000 & 1.000 & 0.960 & 1.000 & 1.000 & 0.980 & 1.000 & 0.993 \\
\hline 2001 & 1.000 & 1.000 & 1.000 & 1.000 & 1.046 & 1.000 & 1.000 & 0.932 & 1.000 & 0.997 \\
\hline 2002 & 1.000 & 1.000 & 1.000 & 1.000 & 1.038 & 1.000 & 1.000 & 0.924 & 1.000 & 0.995 \\
\hline 2003 & 1.000 & 1.000 & 1.000 & 1.000 & 1.077 & 1.000 & 1.000 & 1.185 & 1.000 & 1.027 \\
\hline 2004 & 1.000 & 1.000 & 1.000 & 1.000 & 1.087 & 1.000 & 1.000 & 1.000 & 1.000 & 1.009 \\
\hline 2005 & 1.000 & 1.000 & 1.000 & 1.000 & 0.766 & 1.000 & 1.000 & 1.000 & 1.000 & 0.971 \\
\hline 2006 & 0.869 & 1.000 & 1.000 & 1.000 & 0.964 & 1.000 & 1.000 & 0.992 & 1.000 & 0.980 \\
\hline 2007 & 0.857 & 1.000 & 1.000 & 1.000 & 0.915 & 1.000 & 1.000 & 1.009 & 0.995 & 0.974 \\
\hline 2008 & 1.344 & 1.000 & 1.000 & 1.000 & 1.313 & 1.000 & 1.000 & 1.000 & 1.005 & 1.066 \\
\hline 2009 & 1.000 & 1.000 & 0.972 & 1.000 & 1.127 & 1.000 & 1.000 & 1.000 & 1.000 & 1.010 \\
\hline 2010 & 1.000 & 1.000 & 1.029 & 1.000 & 1.000 & 1.000 & 1.000 & 0.943 & 1.000 & 0.997 \\
\hline 2011 & 0.993 & 1.000 & 1.000 & 1.000 & 0.906 & 1.000 & 1.000 & 0.919 & 1.000 & 0.979 \\
\hline 2012 & 1.007 & 1.000 & 1.000 & 1.000 & 1.094 & 1.000 & 1.000 & 1.146 & 1.000 & 1.026 \\
\hline Average & 1.000 & 1.000 & 1.004 & 1.000 & 1.008 & 1.000 & 1.000 & 1.000 & 1.000 & Average \\
\hline
\end{tabular}

Note that 1981 refers to the change between 1980 and 1981 . 
J. Adv. Agric. Res. (Fac. Agric. Saba Basha)

Appendix (2): Technical Change Results during 1980-2012

\begin{tabular}{|c|c|c|c|c|c|c|c|c|c|c|}
\hline Techch & Algeria & Egypt & Iraq & Jordan & Morocco & Sudan & Syria & Tunisia & Yemen & Average \\
\hline $1981^{*}$ & 1.042 & 0.986 & 1.076 & 1.203 & 1.004 & 1.123 & 0.998 & 0.848 & 0.968 & 1.023 \\
\hline 1982 & 1.058 & 1.015 & 0.923 & 0.793 & 0.961 & 0.883 & 1.009 & 0.994 & 0.972 & 0.953 \\
\hline 1983 & 1.002 & 1.005 & 0.881 & 1.098 & 0.962 & 1.377 & 0.935 & 1.083 & 0.906 & 1.019 \\
\hline 1984 & 1.003 & 0.989 & 0.909 & 1.168 & 0.945 & 0.633 & 0.906 & 0.846 & 0.836 & 0.904 \\
\hline 1985 & 1.073 & 1.035 & 1.056 & 1.050 & 1.032 & 1.132 & 1.085 & 1.128 & 1.150 & 1.082 \\
\hline 1986 & 0.925 & 1.023 & 0.982 & 1.138 & 1.011 & 1.199 & 1.027 & 0.904 & 1.167 & 1.037 \\
\hline 1987 & 1.027 & 1.034 & 0.932 & 0.876 & 0.970 & 1.182 & 0.852 & 1.077 & 1.179 & 1.008 \\
\hline 1988 & 1.090 & 0.985 & 1.104 & 0.818 & 1.178 & 0.791 & 1.206 & 0.869 & 0.818 & 0.972 \\
\hline 1989 & 1.086 & 1.025 & 0.870 & 0.972 & 1.085 & 1.132 & 0.812 & 1.045 & 1.058 & 1.004 \\
\hline 1990 & 0.974 & 1.301 & 1.205 & 1.434 & 0.957 & 0.783 & 1.063 & 1.358 & 0.887 & 1.086 \\
\hline 1991 & 1.093 & 1.019 & 1.061 & 0.998 & 1.077 & 1.321 & 0.989 & 1.161 & 1.085 & 1.085 \\
\hline 1992 & 1.021 & 1.041 & 0.916 & 1.155 & 0.989 & 1.049 & 1.035 & 0.830 & 1.207 & 1.021 \\
\hline 1993 & 1.021 & 0.908 & 1.096 & 0.961 & 0.996 & 0.966 & 1.050 & 1.109 & 1.126 & 1.023 \\
\hline 1994 & 1.020 & 1.047 & 1.001 & 1.180 & 1.043 & 1.100 & 0.991 & 0.933 & 0.939 & 1.026 \\
\hline 1995 & 1.201 & 0.984 & 1.006 & 1.033 & 0.994 & 1.071 & 1.047 & 1.007 & 0.974 & 1.033 \\
\hline 1996 & 1.274 & 1.100 & 1.111 & 0.985 & 1.108 & 0.835 & 1.097 & 1.261 & 1.188 & 1.099 \\
\hline 1997 & 0.634 & 1.015 & 0.916 & 0.941 & 0.935 & 1.106 & 0.961 & 0.730 & 0.760 & 0.877 \\
\hline 1998 & 0.995 & 0.974 & 1.096 & 1.079 & 1.048 & 1.508 & 1.152 & 1.207 & 1.185 & 1.129 \\
\hline 1999 & 1.073 & 1.014 & 0.942 & 0.903 & 0.994 & 0.998 & 0.899 & 1.097 & 1.032 & 0.992 \\
\hline 2000 & 1.052 & 1.053 & 0.941 & 1.210 & 1.018 & 1.014 & 1.142 & 0.850 & 1.077 & 1.035 \\
\hline 2001 & 0.952 & 0.948 & 1.098 & 0.907 & 0.975 & 0.764 & 1.088 & 0.891 & 1.030 & 0.956 \\
\hline 2002 & 1.037 & 1.037 & 1.244 & 1.075 & 1.016 & 1.092 & 1.075 & 1.083 & 1.188 & 1.092 \\
\hline 2003 & 1.609 & 0.968 & 0.815 & 1.262 & 0.970 & 1.105 & 0.932 & 1.324 & 1.488 & 1.136 \\
\hline 2004 & 0.658 & 1.038 & 1.048 & 0.623 & 1.002 & 0.854 & 0.982 & 0.816 & 0.610 & 0.830 \\
\hline 2005 & 1.549 & 1.012 & 0.920 & 1.761 & 1.158 & 1.296 & 0.975 & 1.013 & 1.966 & 1.249 \\
\hline 2006 & 0.929 & 1.154 & 0.950 & 1.068 & 1.138 & 0.985 & 0.993 & 1.128 & 0.747 & 1.002 \\
\hline 2007 & 1.123 & 1.040 & 0.917 & 1.107 & 1.042 & 0.818 & 0.938 & 0.968 & 0.809 & 0.967 \\
\hline 2008 & 0.905 & 0.918 & 0.900 & 0.641 & 0.828 & 0.927 & 1.011 & 0.931 & 1.036 & 0.892 \\
\hline 2009 & 1.026 & 1.089 & 1.045 & 0.885 & 1.123 & 0.850 & 1.331 & 0.922 & 1.162 & 1.039 \\
\hline 2010 & 0.897 & 0.911 & 1.159 & 1.466 & 1.043 & 0.908 & 0.135 & 1.031 & 0.784 & 0.806 \\
\hline 2011 & 1.150 & 1.021 & 1.045 & 1.253 & 1.060 & 1.493 & 0.951 & 1.059 & 1.358 & 1.143 \\
\hline 2012 & 0.962 & 1.033 & 0.973 & 0.887 & 0.945 & 0.681 & 1.020 & 0.965 & 1.134 & 0.948 \\
\hline Average & 1.030 & 1.020 & 0.999 & 1.037 & 1.016 & 1.008 & 0.951 & 1.004 & 1.031 & Average \\
\hline
\end{tabular}

Note that 1981 refers to the change between 1980 and 1981. 
J. Adv. Agric. Res. (Fac. Agric. Saba Basha)

Appendix (3): Total Factor Productivity Results during 1980-2012

\begin{tabular}{|c|c|c|c|c|c|c|c|c|c|c|}
\hline tfpch & Algeria & Egypt & Iraq & Jordan & Morocco & Sudan & Syria & Tunisia & Yemen & Average \\
\hline $1981^{*}$ & 1.042 & 0.986 & 1.085 & 1.203 & 1.042 & 1.123 & 0.998 & 0.848 & 0.968 & 1.028 \\
\hline 1982 & 1.058 & 1.015 & 1.048 & 0.793 & 1.205 & 0.883 & 1.009 & 0.818 & 0.972 & 0.970 \\
\hline 1983 & 1.002 & 1.005 & 0.881 & 1.098 & 0.860 & 1.377 & 0.935 & 1.316 & 0.826 & 1.018 \\
\hline 1984 & 1.003 & 0.989 & 0.754 & 1.168 & 1.046 & 0.633 & 0.906 & 0.846 & 0.917 & 0.905 \\
\hline 1985 & 0.990 & 1.035 & 1.203 & 1.050 & 0.953 & 1.132 & 1.085 & 1.128 & 1.030 & 1.065 \\
\hline 1986 & 1.002 & 1.023 & 0.888 & 1.138 & 1.109 & 1.199 & 1.027 & 0.904 & 1.281 & 1.056 \\
\hline 1987 & 1.027 & 1.034 & 0.940 & 0.876 & 0.969 & 1.182 & 0.852 & 1.077 & 1.199 & 1.011 \\
\hline 1988 & 1.090 & 0.985 & 1.051 & 0.818 & 1.179 & 0.791 & 1.206 & 0.739 & 0.818 & 0.950 \\
\hline 1989 & 1.086 & 1.025 & 1.060 & 0.972 & 1.085 & 1.132 & 0.812 & 1.229 & 1.058 & 1.045 \\
\hline 1990 & 0.974 & 1.301 & 1.075 & 1.434 & 0.957 & 0.783 & 1.063 & 1.358 & 0.826 & 1.064 \\
\hline 1991 & 1.093 & 1.019 & 1.189 & 0.998 & 1.077 & 1.321 & 0.989 & 1.161 & 0.974 & 1.086 \\
\hline 1992 & 1.021 & 1.041 & 0.916 & 1.155 & 0.989 & 1.049 & 1.035 & 0.830 & 1.440 & 1.042 \\
\hline 1993 & 0.986 & 0.908 & 1.096 & 0.961 & 0.996 & 0.966 & 1.050 & 1.109 & 1.129 & 1.020 \\
\hline 1994 & 1.024 & 1.047 & 1.001 & 1.180 & 1.040 & 1.100 & 0.991 & 0.819 & 0.939 & 1.011 \\
\hline 1995 & 1.238 & 0.984 & 1.006 & 1.033 & 0.937 & 1.071 & 1.047 & 1.015 & 0.974 & 1.031 \\
\hline 1996 & 1.274 & 1.100 & 1.111 & 0.985 & 1.179 & 0.835 & 1.097 & 1.425 & 1.188 & 1.121 \\
\hline 1997 & 0.634 & 1.015 & 0.916 & 0.941 & 0.809 & 1.106 & 0.961 & 0.730 & 0.760 & 0.863 \\
\hline 1998 & 0.988 & 0.974 & 1.096 & 1.079 & 1.182 & 1.508 & 1.152 & 1.207 & 1.185 & 1.143 \\
\hline 1999 & 1.081 & 1.014 & 0.942 & 0.903 & 0.836 & 0.998 & 0.899 & 1.097 & 1.032 & 0.974 \\
\hline 2000 & 1.052 & 1.053 & 0.941 & 1.210 & 0.977 & 1.014 & 1.142 & 0.833 & 1.077 & 1.028 \\
\hline 2001 & 0.952 & 0.948 & 1.098 & 0.907 & 1.020 & 0.764 & 1.088 & 0.830 & 1.030 & 0.954 \\
\hline 2002 & 1.037 & 1.037 & 1.244 & 1.075 & 1.055 & 1.092 & 1.075 & 1.001 & 1.188 & 1.087 \\
\hline 2003 & 1.609 & 0.968 & 0.815 & 1.262 & 1.045 & 1.105 & 0.932 & 1.569 & 1.488 & 1.167 \\
\hline 2004 & 0.658 & 1.038 & 1.048 & 0.623 & 1.089 & 0.854 & 0.982 & 0.816 & 0.610 & 0.838 \\
\hline 2005 & 1.549 & 1.012 & 0.920 & 1.761 & 0.887 & 1.296 & 0.975 & 1.013 & 1.966 & 1.213 \\
\hline 2006 & 0.807 & 1.154 & 0.950 & 1.068 & 1.097 & 0.985 & 0.993 & 1.119 & 0.747 & 0.982 \\
\hline 2007 & 0.962 & 1.040 & 0.917 & 1.107 & 0.953 & 0.818 & 0.938 & 0.977 & 0.805 & 0.942 \\
\hline 2008 & 1.216 & 0.918 & 0.900 & 0.641 & 1.087 & 0.927 & 1.011 & 0.931 & 1.041 & 0.951 \\
\hline 2009 & 1.026 & 1.089 & 1.016 & 0.885 & 1.266 & 0.850 & 1.331 & 0.922 & 1.162 & 1.049 \\
\hline 2010 & 0.897 & 0.911 & 1.193 & 1.466 & 1.043 & 0.908 & 0.135 & 0.972 & 0.784 & 0.803 \\
\hline 2011 & 1.142 & 1.021 & 1.045 & 1.253 & 0.960 & 1.493 & 0.951 & 0.973 & 1.358 & 1.119 \\
\hline 2012 & 0.969 & 1.033 & 0.973 & 0.887 & 1.034 & 0.681 & 1.020 & 1.106 & 1.134 & 0.972 \\
\hline Average & 1.030 & 1.020 & 1.004 & 1.037 & 1.025 & 1.008 & 0.951 & 1.004 & 1.031 & Average \\
\hline
\end{tabular}

Note that 1981 refers to the change between 1980 and 1981. 
J. Adv. Agric. Res. (Fac. Agric. Saba Basha)

Appendix (4): Scale Efficiency Results during 1980-2012

\begin{tabular}{|c|c|c|c|c|c|c|c|c|c|c|}
\hline Seff & Algeria & Egypt & Iraq & Jordan & Morocco & Sudan & Syria & Tunisia & Yemen & Average \\
\hline $1981^{*}$ & 1.000 & 1.000 & 0.883 & 1.000 & 0.966 & 1.000 & 1.000 & 1.000 & 1.000 & 0.982 \\
\hline 1982 & 1.000 & 1.000 & 1.135 & 1.000 & 1.048 & 1.000 & 1.000 & 0.958 & 1.000 & 1.015 \\
\hline 1983 & 1.000 & 1.000 & 1.000 & 1.000 & 0.999 & 1.000 & 1.000 & 1.044 & 0.912 & 0.994 \\
\hline 1984 & 1.000 & 1.000 & 0.892 & 1.000 & 1.001 & 1.000 & 1.000 & 1.000 & 1.097 & 0.998 \\
\hline 1985 & 0.923 & 1.000 & 1.087 & 1.000 & 0.985 & 1.000 & 1.000 & 1.000 & 0.896 & 0.987 \\
\hline 1986 & 1.083 & 1.000 & 0.913 & 1.000 & 1.018 & 1.000 & 1.000 & 1.000 & 1.098 & 1.011 \\
\hline 1987 & 1.000 & 1.000 & 0.973 & 1.000 & 0.999 & 1.000 & 1.000 & 1.000 & 1.017 & 0.999 \\
\hline 1988 & 1.000 & 1.000 & 0.952 & 1.000 & 1.001 & 1.000 & 1.000 & 0.935 & 1.000 & 0.987 \\
\hline 1989 & 1.000 & 1.000 & 1.218 & 1.000 & 1.000 & 1.000 & 1.000 & 1.069 & 1.000 & 1.030 \\
\hline 1990 & 1.000 & 1.000 & 0.892 & 1.000 & 1.000 & 1.000 & 1.000 & 1.000 & 0.931 & 0.980 \\
\hline 1991 & 1.000 & 1.000 & 1.121 & 1.000 & 1.000 & 1.000 & 1.000 & 1.000 & 0.898 & 1.001 \\
\hline 1992 & 1.000 & 1.000 & 1.000 & 1.000 & 1.000 & 1.000 & 1.000 & 1.000 & 1.193 & 1.020 \\
\hline 1993 & 0.966 & 1.000 & 1.000 & 1.000 & 1.000 & 1.000 & 1.000 & 1.000 & 1.003 & 0.996 \\
\hline 1994 & 1.004 & 1.000 & 1.000 & 1.000 & 0.997 & 1.000 & 1.000 & 0.878 & 1.000 & 0.986 \\
\hline 1995 & 1.031 & 1.000 & 1.000 & 1.000 & 0.943 & 1.000 & 1.000 & 1.008 & 1.000 & 0.998 \\
\hline 1996 & 1.000 & 1.000 & 1.000 & 1.000 & 1.064 & 1.000 & 1.000 & 1.130 & 1.000 & 1.021 \\
\hline 1997 & 1.000 & 1.000 & 1.000 & 1.000 & 0.871 & 1.000 & 1.000 & 1.000 & 1.000 & 0.985 \\
\hline 1998 & 0.993 & 1.000 & 1.000 & 1.000 & 1.120 & 1.000 & 1.000 & 1.000 & 1.000 & 1.012 \\
\hline 1999 & 1.007 & 1.000 & 1.000 & 1.000 & 0.911 & 1.000 & 1.000 & 1.000 & 1.000 & 0.990 \\
\hline 2000 & 1.000 & 1.000 & 1.000 & 1.000 & 0.978 & 1.000 & 1.000 & 0.980 & 1.000 & 0.995 \\
\hline 2001 & 1.000 & 1.000 & 1.000 & 1.000 & 1.003 & 1.000 & 1.000 & 0.932 & 1.000 & 0.993 \\
\hline 2002 & 1.000 & 1.000 & 1.000 & 1.000 & 1.034 & 1.000 & 1.000 & 0.924 & 1.000 & 0.995 \\
\hline 2003 & 1.000 & 1.000 & 1.000 & 1.000 & 1.110 & 1.000 & 1.000 & 1.185 & 1.000 & 1.031 \\
\hline 2004 & 1.000 & 1.000 & 1.000 & 1.000 & 1.001 & 1.000 & 1.000 & 1.000 & 1.000 & 1.000 \\
\hline 2005 & 1.000 & 1.000 & 1.000 & 1.000 & 0.850 & 1.000 & 1.000 & 1.000 & 1.000 & 0.982 \\
\hline 2006 & 0.869 & 1.000 & 1.000 & 1.000 & 1.010 & 1.000 & 1.000 & 0.992 & 1.000 & 0.985 \\
\hline 2007 & 0.857 & 1.000 & 1.000 & 1.000 & 0.957 & 1.000 & 1.000 & 1.009 & 0.995 & 0.979 \\
\hline 2008 & 1.344 & 1.000 & 1.000 & 1.000 & 1.114 & 1.000 & 1.000 & 1.000 & 1.005 & 1.046 \\
\hline 2009 & 1.000 & 1.000 & 0.972 & 1.000 & 1.091 & 1.000 & 1.000 & 1.000 & 1.000 & 1.007 \\
\hline 2010 & 1.000 & 1.000 & 1.029 & 1.000 & 1.000 & 1.000 & 1.000 & 0.943 & 1.000 & 0.997 \\
\hline 2011 & 0.993 & 1.000 & 1.000 & 1.000 & 0.906 & 1.000 & 1.000 & 0.919 & 1.000 & 0.979 \\
\hline 2012 & 1.007 & 1.000 & 1.000 & 1.000 & 1.094 & 1.000 & 1.000 & 1.146 & 1.000 & 1.026 \\
\hline Average & 1.000 & 1.000 & 1.000 & 1.000 & 1.000 & 1.000 & 1.000 & 1.000 & 1.000 & Average \\
\hline
\end{tabular}

Note that 1981 refers to the change between 1980 and 1981. 
J. Adv. Agric. Res. (Fac. Agric. Saba Basha)

\section{Appendix (5): Pure Efficiency Results during 1980-2012}

\begin{tabular}{|c|c|c|c|c|c|c|c|c|c|c|}
\hline Peff & Algeria & Egypt & Iraq & Jordan & Morocco & Sudan & Syria & Tunisia & Yemen & Average \\
\hline $1981^{*}$ & 1.000 & 1.000 & 1.142 & 1.000 & 1.074 & 1.000 & 1.000 & 1.000 & 1.000 & 1.023 \\
\hline 1982 & 1.000 & 1.000 & 1.000 & 1.000 & 1.196 & 1.000 & 1.000 & 0.859 & 1.000 & 1.003 \\
\hline 1983 & 1.000 & 1.000 & 1.000 & 1.000 & 0.895 & 1.000 & 1.000 & 1.164 & 1.000 & 1.005 \\
\hline 1984 & 1.000 & 1.000 & 0.930 & 1.000 & 1.106 & 1.000 & 1.000 & 1.000 & 1.000 & 1.003 \\
\hline 1985 & 1.000 & 1.000 & 1.048 & 1.000 & 0.937 & 1.000 & 1.000 & 1.000 & 1.000 & 0.998 \\
\hline 1986 & 1.000 & 1.000 & 0.990 & 1.000 & 1.078 & 1.000 & 1.000 & 1.000 & 1.000 & 1.007 \\
\hline 1987 & 1.000 & 1.000 & 1.037 & 1.000 & 1.000 & 1.000 & 1.000 & 1.000 & 1.000 & 1.004 \\
\hline 1988 & 1.000 & 1.000 & 1.000 & 1.000 & 1.000 & 1.000 & 1.000 & 0.909 & 1.000 & 0.989 \\
\hline 1989 & 1.000 & 1.000 & 1.000 & 1.000 & 1.000 & 1.000 & 1.000 & 1.100 & 1.000 & 1.011 \\
\hline 1990 & 1.000 & 1.000 & 1.000 & 1.000 & 1.000 & 1.000 & 1.000 & 1.000 & 1.000 & 1.000 \\
\hline 1991 & 1.000 & 1.000 & 1.000 & 1.000 & 1.000 & 1.000 & 1.000 & 1.000 & 1.000 & 1.000 \\
\hline 1992 & 1.000 & 1.000 & 1.000 & 1.000 & 1.000 & 1.000 & 1.000 & 1.000 & 1.000 & 1.000 \\
\hline 1993 & 1.000 & 1.000 & 1.000 & 1.000 & 1.000 & 1.000 & 1.000 & 1.000 & 1.000 & 1.000 \\
\hline 1994 & 1.000 & 1.000 & 1.000 & 1.000 & 1.000 & 1.000 & 1.000 & 1.000 & 1.000 & 1.000 \\
\hline 1995 & 1.000 & 1.000 & 1.000 & 1.000 & 1.000 & 1.000 & 1.000 & 1.000 & 1.000 & 1.000 \\
\hline 1996 & 1.000 & 1.000 & 1.000 & 1.000 & 1.000 & 1.000 & 1.000 & 1.000 & 1.000 & 1.000 \\
\hline 1997 & 1.000 & 1.000 & 1.000 & 1.000 & 0.993 & 1.000 & 1.000 & 1.000 & 1.000 & 0.999 \\
\hline 1998 & 1.000 & 1.000 & 1.000 & 1.000 & 1.007 & 1.000 & 1.000 & 1.000 & 1.000 & 1.001 \\
\hline 1999 & 1.000 & 1.000 & 1.000 & 1.000 & 0.923 & 1.000 & 1.000 & 1.000 & 1.000 & 0.991 \\
\hline 2000 & 1.000 & 1.000 & 1.000 & 1.000 & 0.982 & 1.000 & 1.000 & 1.000 & 1.000 & 0.998 \\
\hline 2001 & 1.000 & 1.000 & 1.000 & 1.000 & 1.043 & 1.000 & 1.000 & 1.000 & 1.000 & 1.005 \\
\hline 2002 & 1.000 & 1.000 & 1.000 & 1.000 & 1.004 & 1.000 & 1.000 & 1.000 & 1.000 & 1.000 \\
\hline 2003 & 1.000 & 1.000 & 1.000 & 1.000 & 0.970 & 1.000 & 1.000 & 1.000 & 1.000 & 0.997 \\
\hline 2004 & 1.000 & 1.000 & 1.000 & 1.000 & 1.086 & 1.000 & 1.000 & 1.000 & 1.000 & 1.009 \\
\hline 2005 & 1.000 & 1.000 & 1.000 & 1.000 & 0.901 & 1.000 & 1.000 & 1.000 & 1.000 & 0.988 \\
\hline 2006 & 1.000 & 1.000 & 1.000 & 1.000 & 0.954 & 1.000 & 1.000 & 1.000 & 1.000 & 0.995 \\
\hline 2007 & 1.000 & 1.000 & 1.000 & 1.000 & 0.956 & 1.000 & 1.000 & 1.000 & 1.000 & 0.995 \\
\hline 2008 & 1.000 & 1.000 & 1.000 & 1.000 & 1.179 & 1.000 & 1.000 & 1.000 & 1.000 & 1.018 \\
\hline 2009 & 1.000 & 1.000 & 1.000 & 1.000 & 1.033 & 1.000 & 1.000 & 1.000 & 1.000 & 1.004 \\
\hline 2010 & 1.000 & 1.000 & 1.000 & 1.000 & 1.000 & 1.000 & 1.000 & 1.000 & 1.000 & 1.000 \\
\hline 2011 & 1.000 & 1.000 & 1.000 & 1.000 & 1.000 & 1.000 & 1.000 & 1.000 & 1.000 & 1.000 \\
\hline 2012 & 1.000 & 1.000 & 1.000 & 1.000 & 1.000 & 1.000 & 1.000 & 1.000 & 1.000 & 1.000 \\
\hline Average & 1.000 & 1.000 & 1.004 & 1.000 & 1.008 & 1.000 & 1.000 & 1.000 & 1.000 & Average \\
\hline
\end{tabular}

Note that 1981 refers to the change between 1980 and 1981. 


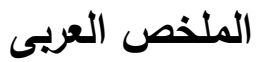

\section{تقدير مؤشر مالمكويست للإنتاجية الكلية للعوامل الزراعية لبعض الدول العربية مستخدماً طريقة مغلف البيانات المنهج اللا معلمى}

\section{أحمد الخولى}

\section{قسم الاقتصاد الزراعى - كلية الزراعة - جامعة المنوفية}

ستستمر الزراعة تلعب دورا حيويا للإنسانية على المستوى العالمى لان الرفاهية البشرية تتوقف على مقدار واستمرار

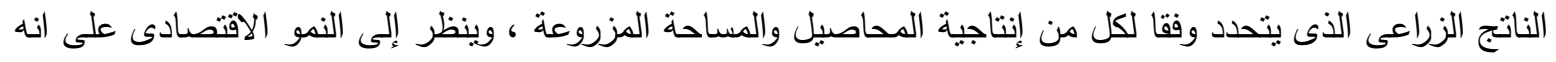

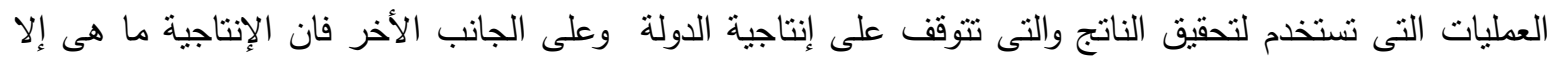
موضوع جزئى يتتاول كيفية قيام الوحدات الإنتاجية باستخدام وتأجير رأس المال والعمل والمدخلات الأخرى في تحقيق لأنى الناتج من السلع و الخدمات ـ والارتباط المباشر بين النمو الاقتصادى والإنتاجية يظهر بعدة طرق ، فمصادر لنمو الإنتاجية مع الزمن تتحقق من النمو والتتمية . ومن الصعب الوصول إلى نمو الإنتاجية كهدف لسياسة التتمية في العديد من الدول ، لهذا السبب فان الدراسات الخاصة بمصادر النمو أصبحت ذات أهميه كبيرة لصناع السياسة ، لذلك فان نمو الإنتاجية قد نال الاهتمام الكبير

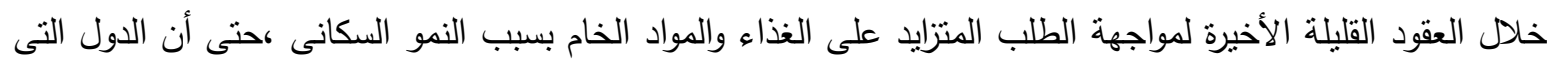
تحقق معدلات منخفضة من نمو الإنتاجية تعاني تدهورا كبيرا فى كلا من ميزان التبادل التجارى وشرط التجارة الداخلى. وقد ألقت العديد من الدراسات الضوء على هذا الموضوع سواء باستخدام أولا مقياس الإنتاجية الجزئية ( والتى نتاولت غالبيتها إنتاجية العمل وثانيا مقياس الإنتاجية الكلية ( PFP)

ينتاول استخدام كل من (1) مدخل الدالة الإنتاجية (2) مدخل الرقم القياسى (3) تحليل مغلف البيانات (DEA)

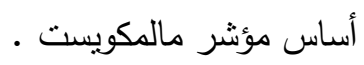

وقد تم تأسيس كلا من موديل الدالة الإنتاجية القياسية باستخدام المربعات الصغرى واجمالى الإنتاجية العامليه عادة باستخدام بيانات السلاسل الزمنية مع افتراض أن جميع الوحدات الإنتاجية تحقق الكفاءة التكنولوجية بينما تحليل مغلف البيانات يكون باستخدام البيانات القطاعية على مستوى المنشآت أو المزارع أو المناطق أو الدول وذلك لمقارنة الإنتاجية النسبية ، فإذا نوافرت جداول البيانات فانه يمكن استخدام الدالات الإنتاجية ، مغلف البيانات ، الدالة الحدوديه العشوائيه لقياس كل من التغير التكنولوجى (Technical Change) وتحسين الإنتاجية (Efficiency Change) .

${ }^{1}$ Partial Factor Productivity (PFP)

Total Factor Productivity (TFP) ${ }^{2}$

Data Envelopment Analysis(DEA) ${ }^{3}$

Vol. 20(1), 2015 
ورقم أو مؤشر مالمكويست والذى أصبح الأوسع استخداما لقياس وتحليل الإنتاجية بعد موديل فاريل ويمكن

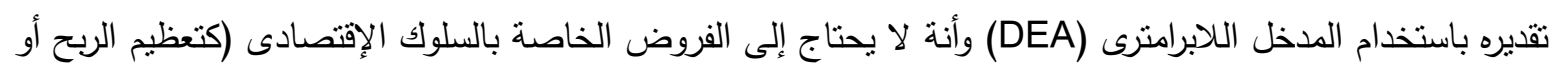
تذنية التكاليف) وبناء على ذلك لا بتطلب إدخال الأسعار في عمليات التقدير هذا بالإضافة إلى إمكانيتها على تقسيم

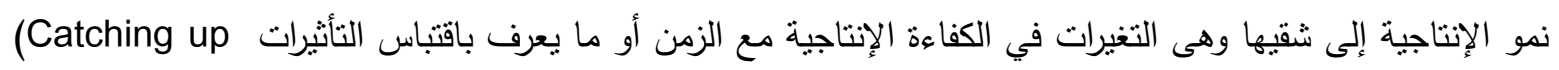

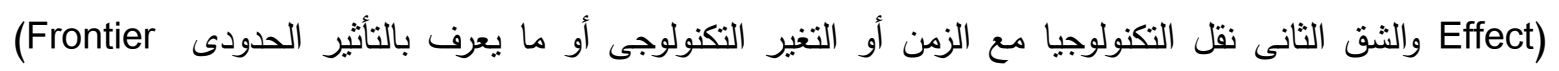
(TFP ) يقيس المسافة بين النقط البيانية لدولة معينة : Effect) في فترتين وبحساب نسبة المسافات لجميع النقط البيانية بالنسبة إلى التكنولوجيا الثائعة فان رقم أو مؤشر مالمكويست

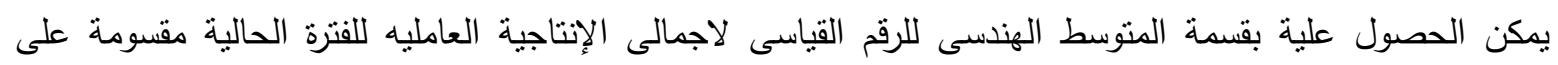

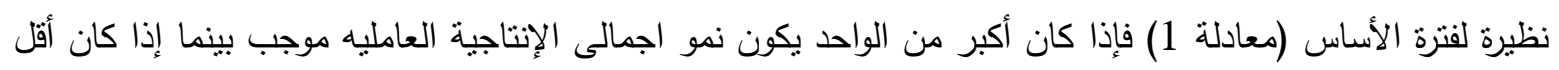
من الواحد يكون النمو سالب . منيره

وتتتاول الدراسة اختبار التغيرات في الإنتاجية الزراعية للدول العربية التى تتسم بارتفاع نسبة مساهمة ناتجها

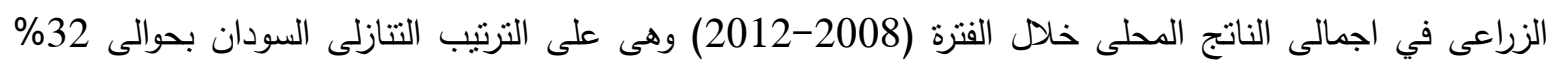
وسوريا بحوالى 21\% ثم المغرب ومصر واليمن بحوالى 14\% ينما الجزائر وتونس بحوالى 8\% ؤوكل من لبنان والعراق بحوالى 5\% والأردن وليبيا والسعودية بحوالى 2,5\% وأخيرا الأمارات العربية وعمان بحوالى 0,9\% بونى وأخيرا البحرين

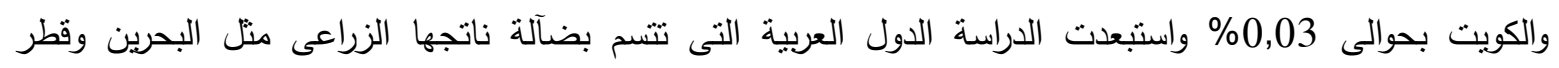
والكويت وعمان والإمارات العربية المتحدة بالإضافة إلى الدول العربية التى لا تتوافر لها بيانات مثل موريتانيا وليبيا

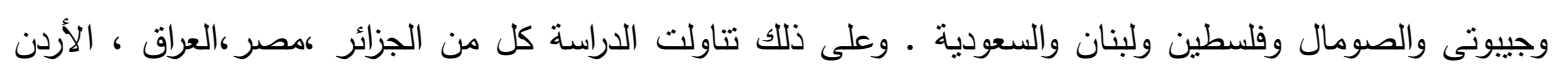
،المغرب ،السودان ، سوريا ، نونس ، اليمن ایى الدول الأكبر انتاجا واستيرادا للطعام والحبوب وتمنت السوق الرئيسية

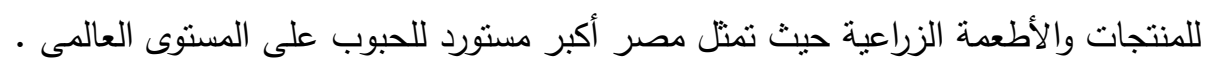

واستخدم التحليل نوعين من المخرجات هما الإنتاج النباتى والإنتاج الحيوانى وتتاول ستة مدخلات هى الأرض

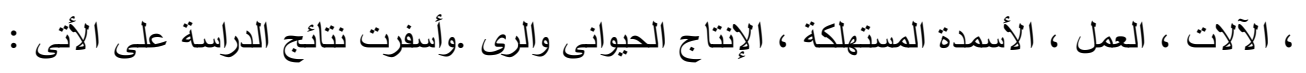

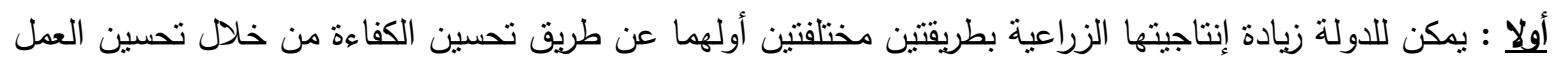
وذلك بنشر التكنولوجيا وثانيهما عن طريق تطبيق التغيرات التكنولوجية من خلال استيراد وتبنى التكنولوجيات الجديدة ومن المؤكد أن الطريقتين معا تزيد من الإنتاجية الزراعية .

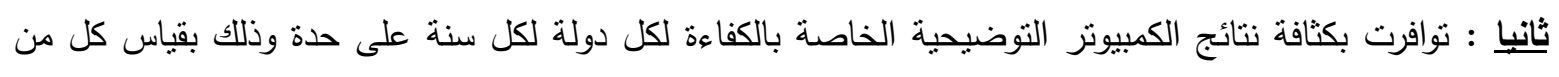

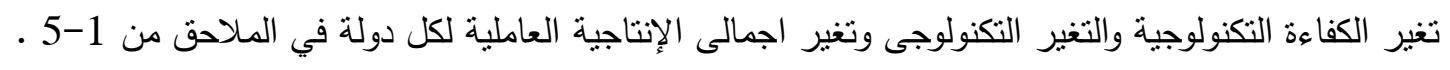
ثالثاً : أظهرت مستويات الكفاءة التكنولوجية لكل دولة النسبة بين الناتج الفعلى والتكنولوجيا الممكنة في كل فترة . لريعا : أظهرت النتائج الخاصة بالكفاءة التكنولوجية على أساس منوسطات فترات الثمانينات والتسعينات والالفينينات انة فيما عدا المغرب واليمن وتونس ان بقية الدول المختارة كانت جميعها ذات كفاءة تكنولوجية خلال الثلاث فترات . الكلمات الدالة: نموذج مغلف البيانات ، مالمكويسيت ، الانتاجية الكلية للعوامل الزراعية . 